\title{
Measuring the duration of formative phases for energy technologies
}

\author{
Nuno Bento ${ }^{a, b, *}$, Charlie Wilson ${ }^{c, d}$ \\ a Sustainability Science Program, Kennedy School of Government, Harvard University, Mailbox 117, 79 JFK \\ street, Cambridge, MA 02138 United States \\ ${ }^{b}$ DINÂMIA'CET, ISCTE-IUL, Av. das Forças Armadas, Edifício ISCTE, Sala 2N19, 1649-026 Lisboa, Portugal \\ c Tyndall Centre for Climate Change Research, University of East Anglia, Norwich, Norfolk NR4 7TJ, UK \\ ${ }^{d}$ Transitions to New Technologies Program, International Institute for Applied Systems Analysis (IIASA), \\ Schlossplatz 1, A-2361 Laxenburg, Austria
}

Version of February 18, 2016

\begin{abstract}
Innovation processes during the early period of a technology's development establish the conditions for widespread commercialization. For comparative analysis of innovation processes across technologies, a common operational definition of the formative phase is needed. This paper develops a set of indicators to measure the start and end points of formative phases with reference to key innovation processes including experimentation and market formation. The indicators are then applied to measure the formative phase durations of sixteen energy technologies covering a range of historical periods and applications. Formative phases are found to last 22 years on average. Determinants of formative phase duration are explored. Duration does not appear to be explained by unit scale, up-scaling, nor initial cost. However, technologies that are ready substitutes for incumbents have shorter formative phases, ceteris paribus. Policy implications include the potentials and risks of accelerating formative phases to push low carbon technologies into the market.
\end{abstract}

Keywords: innovation systems; diffusion; formative phase; indicators; energy technologies.

\footnotetext{
* Corresponding author. Telf.: +3519164160 87; fax: +351217940042

E-mail addresses: Nuno.Bento@iscte.pt (N. Bento); charlie.wilson@uea.ac.uk (C. Wilson)
} 


\section{Introduction}

Limiting climate change in line with the Paris agreement requires energy system transformation and the widespread diffusion of low-carbon technologies. Historical energy transitions show the importance of the early years of a technology's development on subsequent diffusion (Fouquet, 2014, 2008; Smil, 2010). This is often a period of many uncertainties surrounding the formation of a new technology. The formative phase designates the early stage of development that sets up the conditions for a technology to emerge and become established in the market (Wilson and Grubler, 2011).

Two streams of the literature address the challenges faced by a new technology during the formative phase. First, the formative phase has a parallel with the concept of 'era of ferment' in the literature on industry lifecycles (Abernathy and Clark 1985; Abernathy and Utterback, 1978; and for a recent review, Peltoniemi, 2011). An era of ferment is a time of intense technical variation and selection, initiated by a technological breakthrough and culminating with the emergence of a dominant design (Anderson and Tushman, 1990). During this period, the number of firms increases while sales remain relatively low as potential adopters wait for the emergence of a new standard before purchasing. This can be a lengthy process. As an example, 30 product innovations in the US were found to take on average 30 years to move from invention to commercialization, with 14 years more before sales take-off (Agarwal and Bayus, 2002, see also Tellis and Chandrasekaran, 2012; Tellis et al., 2003; Golder and Tellis, 1997). However this literature tends to overlook the systemic conditions (e.g., investment in the production chain, supportive institutions) that often accompany the emergence of new technologies.

Second, formative phases are articulated in the technological innovation systems (TIS) literature, which explains the emergence and growth of an innovation system around a particular technology (Markard et al., 2015; Bergek et al., 2015; Jacobsson and Bergek, 2012; Markard et al., 2012). During the formative phase, constitutive elements of a new innovation system are set up, and essential functions of the emerging innovation system begin influencing the technology's development (Bergek, 2008a; Hekkert et al., 2007).

Experimentation and variety as an outcome of knowledge creation are decisive functions in the early years when a technology is surrounded by many uncertainties in terms of design, function and market demand (Kemp et al, 1998; Rosenberg, 1994). Interactions with established technologies and context can further influence the dynamics of growth (Bergek et al., 2015). Later on, resource mobilization and market formation become more influential functions as technology development shifts towards up-scaling and mass commercialization. Although innovation processes during the formative phase have been characterized in depth, the delineation of the formative phase through time remains unclear. It has been only loosely defined as a period lasting rarely less than a decade, and corresponding to a volume of diffusion that is a fraction of the estimated potential (Bergek et al., 2008a; Markard and Hekkert, 2013). 
This research seeks to understand how long the formative phases of energy technologies last, and how this varies between energy technologies of different type. Specifically, the paper develops an operational definition of formative phase duration drawing on the TIS and industry lifecycle literatures. Indicators of specific innovation processes are proposed to estimate the start and end points of the formative phase consistently for any technology. Application of the indicators is demonstrated on a sample of 16 energy technologies, allowing generic determinants of formative phase duration to be tested empirically.

The main purpose of this work is to provide quantitative estimates of formative phase durations of energy technologies observed historically, and to assess the determining factors of those durations. This meta-analytic purpose, together with our use of some ex post measures applicable to full or completed technology lifecycles, means our work can not be used for prospective technology analysis. However, the insights from history that we can draw help inform current efforts to accelerate the commercialization of low carbon innovations (Winskel and Radcliffe, 2014; Henderson and Newell 2011; Weyant, 2011). This is a novel contribution to the current challenge of climate change mitigation.

The paper is structured as follows. Section 2 reviews the treatment of formative phases in the industry lifecycle and TIS literatures, and identifies relevant innovation processes. Section 3 develops a set of indicators to measure the start and end point of formative phases. Section 4 applies the indicators to a sample of energy technologies and tests potential explanations of the variability in formative phase durations. The paper concludes by discussing implications for energy technology policy in the context of climate change mitigation challenges.

\section{Innovation processes during the formative phase}

\subsection{Industry lifecycles}

Measures of progress through innovation stages have been clearly described in the literature on industry lifecycles (Abernathy and Utterback, 1978). A technological opportunity for new products is created from the pressure exerted by technological advances, changes in customer preferences, or regulation (Abernathy and Clark, 1985). This spurs the entry of many firms introducing different varieties of a product (Klepper, 1996). Increasing entry and rivalry in the early stages of the lifecycle improves the quality of the product, and may also reduce prices, contributing to sales take-off (Agarwal and Bayus, 2002).

The transition to technological maturity is typically characterised by a shift from product to process innovation, the emergence of a dominant design, and a decrease in product variety (Utterback and Abernathy, 1975; Gort and Klepper, 1982; Tushman and Anderson, 1986; Murmann and Frenken, 2006). Reducing uncertainties over technological attributes allows the expansion of production capacity and learning-by-doing economies. As the "era of 
ferment" ends, sales grow rapidly from the large number of potential adopters who wait to purchase the dominant design (Anderson and Tushman, 1990).

The decline in product variety and the shift in the nature of innovation activities help explain the exit of a large number of firms (Utterback and Suarez, 1993). Klepper (1997) proposes the notion of "shake-out" for the period of time during which the number of firms decreases as the market grows. This marks the end of the formative phase.

Other indicators of innovation activities during the formative phase focus on sales prior to market growth (Peres et al., 2010). Kohli et al. (1999) find that the "incubation time" of an innovation before market launch relates to subsequent diffusion. Golder and Tellis (1997) estimate the time from introduction to sales take-off of 31 innovations in the US and find significant variation as a function of price and market penetration.

In the specific case of energy technologies, the end of the formative phase is also marked by a transition from experimentation and production of many small scale units to an up-scaling phase which can see rapid increases in the maximum unit sizes of a technology (Wilson, 2012). Up-scaling to capture scale economies is a powerful and constant background condition of technology development, and a common heuristic in innovation systems (Winter, 2008).

\subsection{Innovation systems}

The role of the formative phase in the emergence of new technologies can also be analysed through the lens of the technological innovation system (TIS). A systemic perspective is well suited to analyse complex and interdependent energy technology innovation (Grubler and Wilson 2014). The TIS literature identifies and elaborates the key innovation processes that take place during the formative phase.

The TIS is a "network of agents interacting in a specific economic/industrial area under a particular institutional infrastructure or set of infrastructures and involved in the generation, diffusion, and utilization of technology" (Carlsson and Stankiewicz, 1991: 111). According to this definition, the three main elements of a TIS are actors, networks and institutions (Bergek et al., 2008a; Jacobsson and Bergek, 2004). Actors include firms and other organizations (e.g. universities, industry associations) along the value chain (Bergek et al., 2008a). Networks link disparate actors to perform a particular task (e.g. knowledge share, lobby). Institutions consist of formal rules (e.g., laws and property rights) and informal norms (e.g. tradition and culture) that structure political, economic and social interactions.

The emergence of a new TIS has been typically analysed in terms of the development of its key structural elements including (Jacobsson, 2008): entry of firms and other organizations; formation of networks; and institutional alignment. A more recent approach also analyses key innovation processes or functions (Bergek et al, 2008b; Hekkert et al., 2007). Table 1 
(first column) summarises seven important innovation system functions. The performance of these functions provides indications about the effective functioning of innovation systems.

Interactions between a subset of four functions have been associated with virtuous cycles of development in the emergence of new innovation systems (Suurs et al., 2010). These four functions are: knowledge creation, entrepreneurial experimentation, influence on the direction of search, and market formation (Suurs et al., 2009; Hekkert and Negro, 2009).

'Knowledge creation' refers to how knowledge is generated, combined, codified and shared to establish the necessary scientific and technological base for an innovation to progress (Jacobsson and Bergek, 2012). 'Experimentation' refers to the development of a more applied, tacit and explorative knowledge by risk-taking and hence 'entrepreneurial' actors in the innovation system. 'Influence on the direction of search' relates to the mechanisms that influence how new actors in the innovation system allocate their activities and investments between competing technologies and designs (Bergek et al., 2008b). 'Market formation' refers to the articulation of demand around increasingly organized markets, from demonstration projects to niches and bridging markets which enable increasing volumes of production before mass commercialization (Bergek et al., 2008a; Hekkert et al., 2009).

As the innovation approaches mass commercialisation, other innovation system functions become increasingly important. These include materialisation, resource mobilization, and legitimation as well as continued market formation (Bergek et al., 2008b). Clear evidence of these functions signals the end of the formative phase.

'Materialisation' describes the first major investments in capital stock or artefacts (e.g. factories, infrastructure). 'Resource mobilisation' refers to the need to draw in human capital, financial capital and complementary assets from outside the innovation system. Finally, 'legitimation' is a socio-political process by which actors' expectations are formed and shared, creating a network of potentially diverse actors as a coalition of advocates for the technology's development (Bergek et al., 2008a; Borup et al., 2006). 'Legitimation' can play a key role in the cumulative strengthening of innovation systems by aligning institutions with the needs of the emerging innovation (Hekkert and Negro, 2009).

Both the performance of each system function and the interactions between them are necessary during the formative phase, along with the structural processes described above. The performance of more system functions is likely to enhance development of the TIS in terms of the generation, diffusion, and utilization of the new technology. In contrast, underperformance of the system functions will hinder development of the TIS. Various indicators have been used to track performance of individual innovation system functions (Table 1). Applying indicators is not straightforward, and in many cases it is difficult to objectively quantify comparable indicators. Examples include measuring expectations and their implications for diffusion, or clearly defining legitimation. However, they provide helpful information to map the emergence of new innovation systems. 
The functional and structural processes should co-evolve with the technology to prepare the innovation system for expansion. Table 2 summarizes the contributions of both the industry lifecycle literature and the technology innovation system (TIS) literature to the understanding of the formative phase.

Table 1. Indicators used to measure innovation system functions (Sources: Bergek et al., 2008a,b; Hekkert et al., 2007; Vasseur et al., 2013; Gosens and Lu, 2013)

\begin{tabular}{|c|c|c|}
\hline System function * & Indicators & Application issues \& challenges \\
\hline Knowledge creation & $\begin{array}{l}\text { R\&D funding and activities. } \\
\text { Scientific publication and patenting. } \\
\text { Research networks (knowledge exchange). } \\
\text { Workshops and conferences. }\end{array}$ & $\begin{array}{l}\text { Distinguishing basic from applied R\&D. } \\
\text { Comparing data on networks, } \\
\text { workshops and conferences. }\end{array}$ \\
\hline $\begin{array}{l}\text { Entrepreneurial } \\
\text { experimentation }\end{array}$ & $\begin{array}{l}\text { Studies, demonstration pilots, field trials activities. } \\
\text { Number of firms (new entrants and diversification of } \\
\text { activities of incumbents). }\end{array}$ & $\begin{array}{l}\text { Distinguishing experimentation from } \\
\text { deployment. }\end{array}$ \\
\hline Materialisation & $\begin{array}{l}\text { New factories opened. } \\
\text { Investment in new production plants, physical } \\
\text { infrastructure. }\end{array}$ & $\begin{array}{l}\text { Separating materialisation from resource } \\
\text { mobilization. }\end{array}$ \\
\hline $\begin{array}{l}\text { Influence on the } \\
\text { direction of search }\end{array}$ & $\begin{array}{l}\text { Targets set by government or industry (e.g. roadmaps). } \\
\text { Expectations and opinions of experts. } \\
\text { Articulation of demand by leading consumers. }\end{array}$ & $\begin{array}{l}\text { Measuring expectations and their } \\
\text { implications for diffusion. }\end{array}$ \\
\hline Market formation & $\begin{array}{l}\text { Policies that stimulate market formation and expansion } \\
\text { (e.g. protected niches, regulatory or fiscal instruments). } \\
\text { Sales, unit numbers. } \\
\text { Installed capacity. }\end{array}$ & $\begin{array}{l}\text { Establishing if sales growth is } \\
\text { permanent and represents take-off. }\end{array}$ \\
\hline Resource mobilisation & $\begin{array}{l}\text { Financial investments. } \\
\text { Human capital and complementary assets. }\end{array}$ & $\begin{array}{l}\text { Quantifying human capital and } \\
\text { complementary assets. }\end{array}$ \\
\hline Legitimation & $\begin{array}{l}\text { Recognition of societal benefits (e.g. awards, } \\
\text { competitions, brochures). } \\
\text { Technical assessment studies. } \\
\text { Public debates (e.g. parliament, media). } \\
\text { Lobbying activities. } \\
\text { Alignment of science and technology policy, and other } \\
\text { institutions. }\end{array}$ & $\begin{array}{l}\text { Confining definition of legitimation. } \\
\text { Quantifying social recognition, public } \\
\text { debates or lobbying activities. }\end{array}$ \\
\hline
\end{tabular}

* Development of positive externalities is included as an additional innovation system function in some studies and refers to the exploitation of synergies with other innovation systems (Bergek et al., 2008b).

Table 2. Conceptualization of the formative phase

\begin{tabular}{lll}
\hline & $\begin{array}{l}\text { Formative Phase in the Industry Lifecycle } \\
\text { literature (e.g., Peltoniemi, 2011) }\end{array}$ & $\begin{array}{l}\text { Formative Phase in the Technological Innovation System } \\
\text { (TIS) literature (e.g, Bergek, 2008a; Hekkert et al., 2007) }\end{array}$ \\
\hline Definition & $\begin{array}{l}\text { Period of intense technical variation leading } \\
\text { to the emergence of a dominant design }\end{array}$ & $\begin{array}{l}\text { Time to set up constitutive elements and essential } \\
\text { processes of the TIS }\end{array}$ \\
$\begin{array}{ll}\text { Mechanism } \\
\text { Improvement of technology quality and }\end{array}$ & $\begin{array}{l}\text { System structuration and performance of key functions } \\
\text { focus }\end{array}$ \\
$\begin{array}{l}\text { Main actors } \\
\text { reduction of costs }\end{array}$ & Firms & Innovation system (including institutions) \\
\end{tabular}




\subsection{Formative processes in the emergence of innovation systems}

Formative phases within innovation system development is a relatively recent focus of research (Markard and Hekkert, 2013). A common approach for identifying the formative phase is to compare and contrast the changing state of the innovation system over time. Bergek et al. (2008a) distinguish between a formative phase when "... constituent elements of the new TIS begin to be put into place..." (p. 419) and a growth phase when "... the focus shifts to system expansion and large-scale technology diffusion through the formation of bridging markets and subsequently mass markets..." (p. 420).

Table 3 summarises the changes in innovation systems as they grow and evolve through different stages: nascent, emerging, strengthening, mature. During each stage, the innovation system is characterised by differences in technology characteristics, structural elements (actors, institutions, networks), and key functions (Markard and Hekkert, 2013). The "nascent" TIS in the start of the formative phase is marked by the existence of a large variety of ideas and concepts. The structure of the innovation system comprises a small number of actors organized mainly in networks dedicated to R\&D activities and knowledge creation. Jacobsson (2008) and Markard and Hekkert (2013) consider early trials and demonstrations to also be part of the nascent stage of TIS development.

In contrast, the "emerging" TIS at the end of the formative phase is evidenced by a more stable technology design and a gradually more structured innovation system. The key processes that play a more influential role include market formation and strengthening expectations (guiding the direction of search). This process is complex and typically in competition with other technologies. An increasing number of actors also reinforces the political strength of advocacy coalitions helping to align institutions with the needs of the innovation system (Bergek et al., 2008a; Borup et al., 2006). 
Table 3. Stages of maturation of technological innovation systems (adapted from Markard and Hekkert, 2013).

\begin{tabular}{|c|c|c|c|c|}
\hline & Nascent TIS* & Emerging TIS & Strengthening TIS & Mature TIS \\
\hline Technology & $\begin{array}{l}\text { Post-invention; } \\
\text { variety of ideas and } \\
\text { concepts }\end{array}$ & $\begin{array}{l}\text { "Childhood"; } \\
\text { selection of first } \\
\text { prototypes; } \\
\text { retention of a small } \\
\text { number of designs }\end{array}$ & $\begin{array}{l}\text { Dominant design; scaling } \\
\text { up technology }\end{array}$ & $\begin{array}{l}\text { Standardised } \\
\text { product; mass } \\
\text { production }\end{array}$ \\
\hline $\begin{array}{l}\text { Degree of } \\
\text { structuration } \\
\text { - Actors }\end{array}$ & $\begin{array}{l}\text { Low (or absent); } \\
\text { early formation } \\
\text { Very few actors: } \\
\text { mainly inventors, } \\
\text { private and public } \\
\text { research labs, } \\
\text { universities }\end{array}$ & $\begin{array}{l}\text { Medium; late } \\
\text { formation } \\
\text { Medium number of } \\
\text { actors: private and } \\
\text { public } \\
\text { organizations; high } \\
\text { entry/exit rates }\end{array}$ & $\begin{array}{l}\text { Medium-high; } \\
\text { transitional } \\
\text { Medium to large number } \\
\text { of actors: more private } \\
\text { organizations; decreasing } \\
\text { number of firms; higher } \\
\text { exit rates }\end{array}$ & $\begin{array}{l}\text { Large number of } \\
\text { actors: different } \\
\text { kinds of } \\
\text { organizations; small } \\
\text { number of firms; } \\
\text { low entry/exit }\end{array}$ \\
\hline - Institutions & $\begin{array}{l}\text { Very few; mostly } \\
\text { informal and } \\
\text { cognitive (ideas, } \\
\text { expectations) }\end{array}$ & $\begin{array}{l}\text { Dynamic number of } \\
\text { technology-specific } \\
\text { institutions }\end{array}$ & $\begin{array}{l}\text { Stabilizing number of } \\
\text { technology-specific } \\
\text { institutions }\end{array}$ & $\begin{array}{l}\text { Stable formal and } \\
\text { informal } \\
\text { technology-specific } \\
\text { institutions }\end{array}$ \\
\hline - Networks & $\begin{array}{l}\text { Constitution of } \\
\text { knowledge and R\&D } \\
\text { networks }\end{array}$ & $\begin{array}{l}\text { Diversification of } \\
\text { the type of } \\
\text { networks (e.g., } \\
\text { R\&D, deployment, } \\
\text { lobbying) }\end{array}$ & $\begin{array}{l}\text { Different types of } \\
\text { networks (cognitive and } \\
\text { technological) }\end{array}$ & $\begin{array}{l}\text { Established industry } \\
\text { networks }\end{array}$ \\
\hline $\begin{array}{l}\text { Key } \\
\text { functions }\end{array}$ & $\begin{array}{l}\text { Knowledge } \\
\text { creation, } \\
\text { Experimentation, } \\
\text { Direction of search }\end{array}$ & $\begin{array}{l}\text { Knowledge } \\
\text { creation, } \\
\text { Experimentation, } \\
\text { Direction of search, } \\
\text { Market formation }\end{array}$ & $\begin{array}{l}\text { Resource mobilisation, } \\
\text { Legitimation, } \\
\text { Market formation }\end{array}$ & All functions \\
\hline
\end{tabular}

* Including 'incubation time' of the innovation, i.e. the development time prior to introduction.

\section{Indicators of the start and end points of formative phases}

The previous section articulated the formative phase in terms of technology characteristics, innovation system elements and functions. This provides a clearer basis for choosing indicators that can measure formative phase durations in a standardised and comparable way. Estimating formative phase durations consistently across technologies allows the determinants of more rapid formative phases to be identified and tested. This has not been done to-date, yet is of major current policy interest in response to climate change mitigation challenges. 
This paper proposes a range of indicators for the start and end of the formative phase, building on the formative phase processes shown in Table 3 and the indicators used in the literature to characterise innovation system functions shown in Table 1. Additional indicators are compiled using industry lifecycle characteristics including the number of firms, shakeout, and cost reductions.

\subsection{Start point indicators}

Table 4 presents the indicators and associated metrics for the start points of formative phases. The indicators are: (S1) first 'embodiment' of technology; (S2) first commercial application; (S3) first sequential commercialization. Linkages between each indicator and innovation system functions at the beginning of the formative phase are shown in Table 4. These include important system functions in early years such as knowledge creation, experimentation, and market formation.

First embodiment of technology (S1) was chosen because of the importance for technology development of learning obtained from the first trials (Hendry et al., 2010), and its correspondence with applied knowledge creation as a key innovation process. First commercial application (S2) has been considered in previous studies (e.g. Mensch, 1979) and is a mark in the development of innovation systems, particularly in the growth of entrepreneurial experimentation. First sequential commercialisation (S3) is an important indicator of transition from pre-commercial experimentation to more sustained production as a basis for learning and specifically for early market formation. Overall these indicators show the direction of search and mark the progress of the new technology, as well as the increasing dynamics of the emerging innovation system.

Additional indicators were considered but rejected due to lack of data. These include first peak in R\&D expenditure (see Appendix B). They are explained in detail in a separate technical report (Bento and Wilson, 2014). 
Table 4. Indicators to define start point of formative phase

\begin{tabular}{|c|c|c|c|c|}
\hline & Indicator & Metric & $\begin{array}{l}\text { Link to Innovation } \\
\text { System Functions }\end{array}$ & Rationale \\
\hline S1 & $\begin{array}{l}\text { First } \\
\text { 'embodiment' of } \\
\text { technology }\end{array}$ & $\begin{array}{l}\text { - year of first significant } \\
\text { prototype or } \\
\text { demonstration of the } \\
\text { innovation }\end{array}$ & $\begin{array}{l}\text { knowledge creation, } \\
\text { experimentation }\end{array}$ & $\begin{array}{l}\text { learning derived from } \\
\text { experimentation and trials articulates } \\
\text { possibilities for producing and } \\
\text { marketing the innovation (Harborne } \\
\text { and Hendry, 2009; Garud and Karnøe, } \\
\text { 2003) }\end{array}$ \\
\hline$S 2$ & $\begin{array}{l}\text { First commercial } \\
\text { application }\end{array}$ & $\begin{array}{l}\text { year of first application } \\
\text { outside the lab or } \\
\text { beginning of technology } \\
\text { production }\end{array}$ & $\begin{array}{l}\text { Experimentation, } \\
\text { Knowledge creation }\end{array}$ & $\begin{array}{l}\text { technology put into production for the } \\
\text { first time, or market created, raises } \\
\text { applied knowledge and confidence in } \\
\text { a new product (Mensch, 1979) }\end{array}$ \\
\hline$S 2 a$ & & $\begin{array}{l}\text { - measured using } \\
\text { innovation lists (e.g. } \\
\text { Mensch, 1979) }\end{array}$ & & \\
\hline$S 2 b$ & & $\begin{array}{l}\text { - measured using own } \\
\text { research }\end{array}$ & & \\
\hline S3 & $\begin{array}{l}\text { First sequential } \\
\text { commercialization }\end{array}$ & $\begin{array}{l}\text { - year of first commercial } \\
\text { application initiating } \\
\text { successive series of } \\
\text { product (i.e., not just a } \\
\text { one-off) }\end{array}$ & $\begin{array}{l}\text { knowledge creation, } \\
\text { market formation }\end{array}$ & $\begin{array}{l}\text { transition from pre-commercial } \\
\text { experimentation enables decisive } \\
\text { production and repeat market } \\
\text { experience }\end{array}$ \\
\hline
\end{tabular}

\subsection{End point indicators}

Table 5 presents the indicators and associated metrics for the end points of formative phases. These include both indicators of technology supply and market demand.

Technology supply indicators reveal growth in production capacity (e.g., the entry of actors, development of networks, build-up of value chains, alignment of regulation - reflecting an increasingly structured TIS), as well as indirectly show a technology's design maturity. The indicators are: (E1) numbers of units produced and capacity installed; (E2) up-scaling. These indicators were demonstrated empirically in a study of wind power development (Wilson 2012). In both cases, a 10\% threshold is used. Marchetti and Nakicenovic (1979) first proposed a metric for time durations of technological substitution, with the changeover time, $\Delta$ t, being the time to grow from 10 to $90 \%$ market share. $10 \%$ of eventual saturation is therefore a recognised milestone. As an example, Grubler (2012) finds that at the global level, characteristic changeover times in primary energy span 80 to 130 years. The indicators relate to specific innovation system functions. The number of installations indicate market formation, and technology up-scaling reveals the choice of design or standard which reinforces the direction of search.

Market demand indicators provide information about learning-by-using and on the market readiness of a technology. The indicators are: (E3) market structure; (E4) cost reduction; (E5) user adoption. These indicators have been widely applied in technology lifecycle and 
management studies (Klepper 1997; Agarwal and Bayus, 2002; Rogers, 2003). Linkages to innovation system functions include: number of companies indicating resource mobilisation; learning and cost reduction evidencing market formation; and adoption by the "innovators" group demonstrating legitimation. Additional indicators were considered but rejected due to lack of data. These include number of patents, dominant designs, and production scale up (see Appendix C). They are explained in detail in a separate technical report (Bento and Wilson, 2014).

Although most of the indicators can be tracked as a technology progresses through the formative phase, the two technology supply indicators (E1 \& E2) can only be identified ex post as shares of observed market saturation levels. 
Table 5. Indicators to define end point of formative phase

\begin{tabular}{|c|c|c|c|c|c|}
\hline Type & & Indicator & Metric & $\begin{array}{l}\text { Link to Innovation } \\
\text { System Functions }\end{array}$ & Rationale \\
\hline \multirow{2}{*}{ 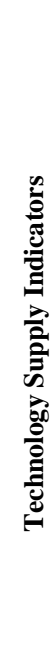 } & $\begin{array}{l}E 1 \\
\text { E1a }\end{array}$ & $\begin{array}{l}\text { Units produced and } \\
\text { capacity installed }\end{array}$ & $\begin{array}{l}\text { year when } 10 \% \text { of } \\
\text { eventual saturation level } \\
\text { is reached (identified ex } \\
\text { post) } \\
\text { - cumulative total unit } \\
\text { numbers } \\
\text { - cumulative total } \\
\text { installed capacity }\end{array}$ & $\begin{array}{l}\text { legitimation, } \\
\text { resource mobilisation, } \\
\text { market formation }\end{array}$ & $\begin{array}{l}\text { transition from } \\
\text { experimentation } \\
\text { with many unit } \\
\text { numbers to mature } \\
\text { market growth and } \\
\text { production scale } \\
\text { up (Wilson, 2012) }\end{array}$ \\
\hline & $E 2$ & $\begin{array}{l}\text { Up-scaling of unit } \\
\text { size }\end{array}$ & $\begin{array}{l}\text { - year when } 10 \% \text { of } \\
\text { maximum unit capacity } \\
\text { is reached (identified ex } \\
\text { post) }\end{array}$ & $\begin{array}{l}\text { direction of search, } \\
\text { legitimation }\end{array}$ & $\begin{array}{l}\text { knowledge and } \\
\text { institutions } \\
\text { necessary to } \\
\text { support economies } \\
\text { of scale are in } \\
\text { place (Winter, } \\
\text { 2008) }\end{array}$ \\
\hline \multirow{3}{*}{ 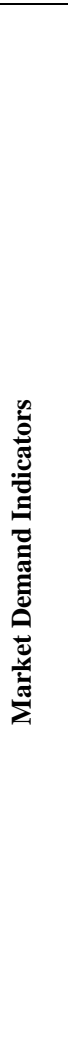 } & $\begin{array}{l}E 3 \\
E 3 a \\
E 3 b\end{array}$ & Market structure & $\begin{array}{l}\text { year when numbers of } \\
\text { firms peaks or changes } \\
\text { - number of firms peak } \\
\text { - pronounced (>30\%) } \\
\text { and sustained fall in } \\
\text { number of firms from } \\
\text { peak (termed "shake- } \\
\text { out" by Klepper, } \\
\text { 1997:165) }\end{array}$ & $\begin{array}{l}\text { market formation, } \\
\text { resource mobilisation, } \\
\text { legitimation }\end{array}$ & $\begin{array}{l}\text { expectations } \\
\text { become more } \\
\text { robust, lowering } \\
\text { risk in scale } \\
\text { investments; } \\
\text { increasing } \\
\text { competition and } \\
\text { resource } \\
\text { requirements } \\
\text { mean firms exit } \\
\text { market (Klepper, } \\
\text { 1996) }\end{array}$ \\
\hline & $E 4$ & Cost reduction & $\begin{array}{l}\text { - year of highest relative } \\
\text { year-on-year cost } \\
\text { reduction }\end{array}$ & $\begin{array}{l}\text { market formation, } \\
\text { legitimation }\end{array}$ & $\begin{array}{l}\text { learning-by-doing } \\
\text { (Arrow, 1962); } \\
\text { institutional } \\
\text { capacity } \\
\text { established to } \\
\text { support learning } \\
\text { economies }\end{array}$ \\
\hline & $E 5$ & User adoption & $\begin{array}{l}\text { - year when } 2.5 \% \text { of } \\
\text { maximum potential } \\
\text { adopters have adopted } \\
\text { (“innovators" category } \\
\text { identified by Rogers, } \\
2003 \text { ) }\end{array}$ & $\begin{array}{l}\text { legitimation, } \\
\text { market formation }\end{array}$ & $\begin{array}{l}\text { learning-by-using; } \\
\text { reduction in } \\
\text { perceived } \\
\text { technological } \\
\text { uncertainty and } \\
\text { adoption risk } \\
\text { (Rosenberg, 1982) }\end{array}$ \\
\hline
\end{tabular}

\subsection{Estimating durations}

\section{Formative phase durations can be estimated by differencing the start and end point} indicators. Figure 1 provides an example for passenger cars in the US. Results from all available indicators are compared to find the earliest estimate of the start point (minimum or leftmost dot) and the latest estimate of the end point (maximum or rightmost cross). This 
sets the upper bound for formative phase duration (light blue bar), expressing the uncertainties associated with competing indicators. A central estimate of formative phase duration (dark blue bar) spans the time period between preferred indicators of start and end points which are consistent across all technologies (see below). This narrows the gap to a more plausible interval that can be comparable across technologies.

Figure 1. Estimating formative phase durations and uncertainties, using passenger cars in the US as an example.

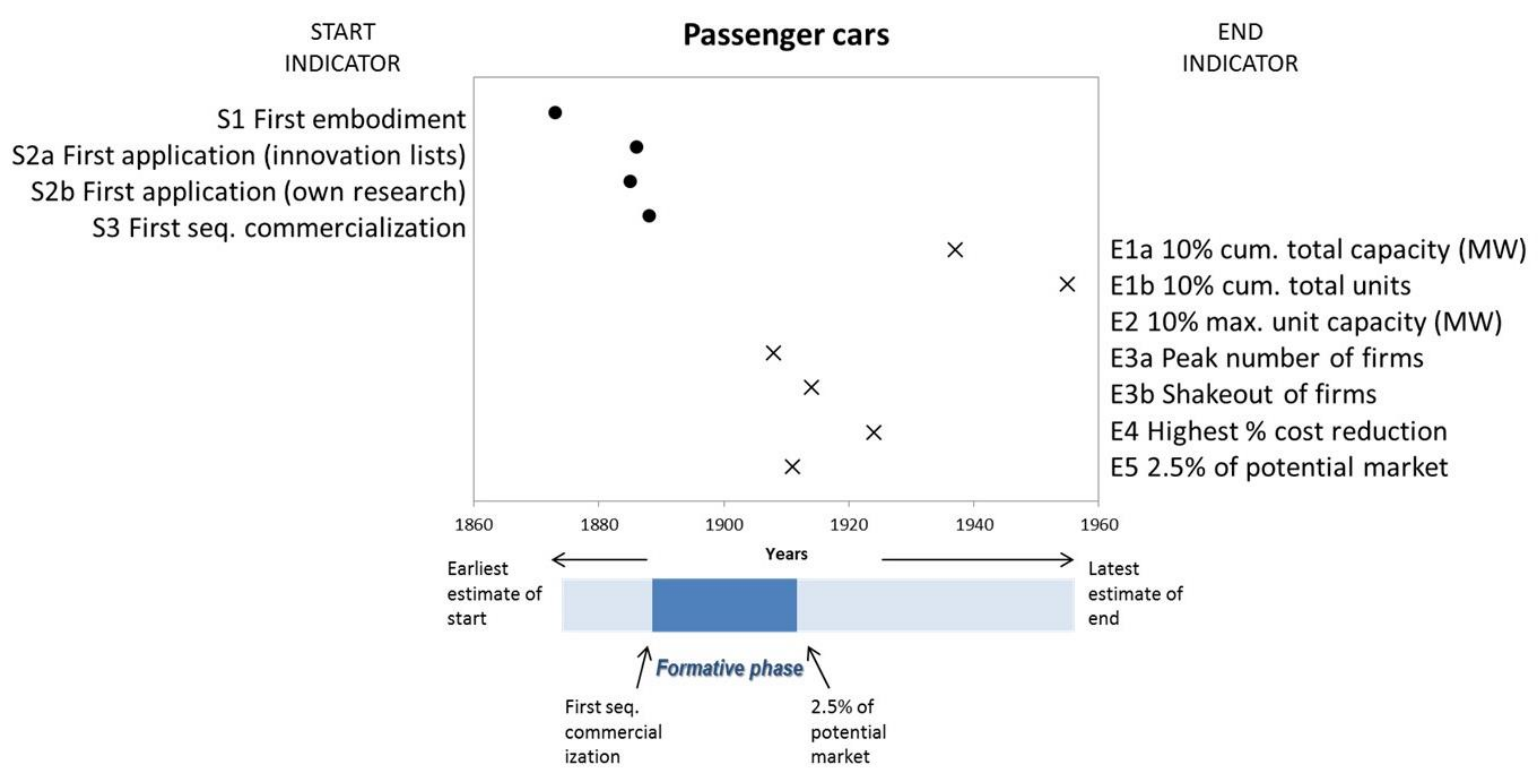

\section{Formative phase durations of energy technologies}

\subsection{Applying the indicators}

To demonstrate how the proposed indicators can be used to consistently measure formative phase durations across diverse technologies, we compiled data characterising a sample of 16 energy technologies that have diffused into the mass market and so transitioned out of their formative phases. The sample was not designed to be exhaustive but to cover a diverse range of technologies. It comprises: (1) energy supply and end-use, (2) large and small technologies, and (3) historical and current technologies (see Appendix A). Following Murmann and Frenken (2006), technologies are defined as the highest level of complexity and aggregation of component parts excluding distribution infrastructure and commercialization (e.g., power plants rather than electricity systems or steam turbine units). Unless otherwise mentioned, the spatial scale of analysis always corresponds to the initial markets of first commercial application for each technology in which the formative phases marked the emergence of a new innovation system. As examples, wind power is analysed in Denmark, cars in the US, e-bikes in China (see Appendix A for details). A synthesis of all relevant data and sources is included in Appendices $B$ and $C$, and elaborated in detail in a separate technical report (Bento and Wilson, 2014). 
The diffusion dynamics of sampled technologies in their initial markets are shown in Figure 2. The graph shows rising market shares in these initial markets from the point when each technology passed a threshold of $0.1 \%$ of its eventual maximum installed capacity. This makes it easier to compare between technologies and removes the annual growth volatility of the very early diffusion period. Maximum capacities or saturation levels are either observed (e.g., steam engines) or estimated using fitted logistic functions to observations, subject to goodness of fit criteria (e.g., wind power). Saturation levels are only estimated in the mature initial markets of first commercialisation. Full details of the saturation level estimations are provided in a separate technical report (Bento and Wilson 2014).

The sample includes technologies showing relatively fast diffusion (e.g. e-bikes, compact fluorescent lamps or CFLs) as well as those with much slower market progression (e.g. motorcycles, cars, bicycles). Mobile phones are not included in Figure 2 as the saturation level is still uncertain.

Figure 2. Diffusion of energy technologies in their initial markets

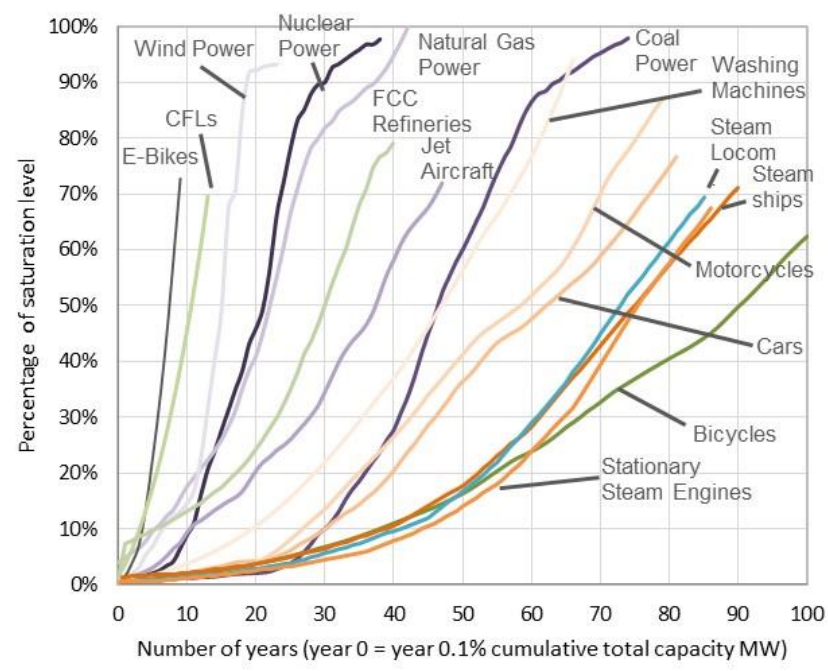

\subsection{Selecting preferred indicators}

Different indicators of the start and end points of the formative phase are shown in Figure 3 for the sampled technologies ordered historically by the year of invention, from the earliest (at the top) to the latest (at the bottom). The periods between start and end indicators reveal long formative phases spanning several decades. Durations are longer in the case of older, general purpose technologies like steam engines which had to wait for the development of complementary innovations before their pervasive impact across several sectors of the economy could be achieved (Rosenberg and Trajtenberg, 2004). 
Figure 3. Indicators of the start and end points of formative phases in initial markets. (Technologies ordered historically by year of invention).

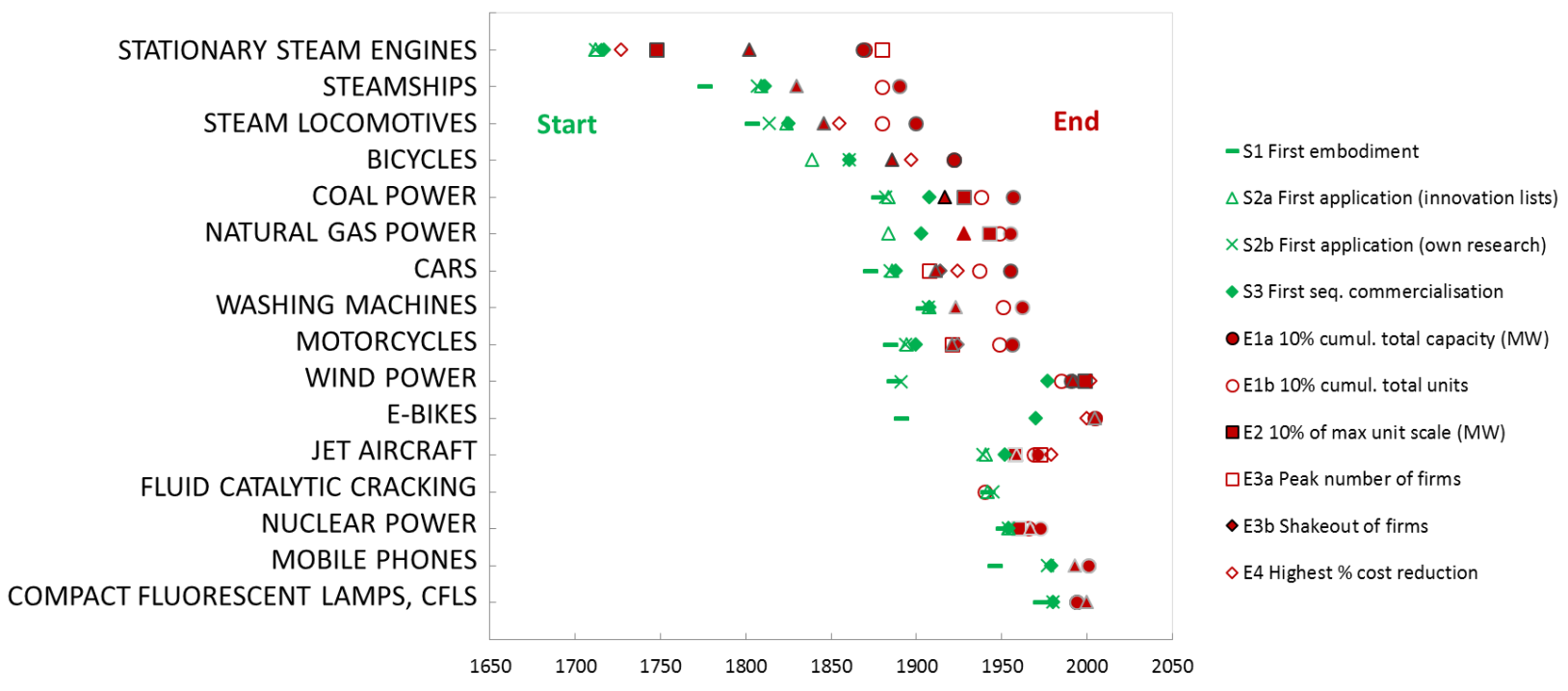

Of the indicators for the start point of the formative phase, (S1) 'first embodiment' is generally the earliest date whereas (S2) 'first application' and then (S3) 'first sequential commercialization' provide later estimates, as expected. The start point indicators tend to converge, apart from in certain cases such as wind power and e-bikes. For both technologies, initial innovation and first applications were in the 1890s but the first sequential commercialisation observed in the data did not begin until almost a century later in Denmark and China respectively.

A single preferred indicator is needed for consistency when comparing formative phases across technologies. Three criteria were used to select a preferred indicator: (i) correspondence with formative phase processes identified in the literature; (ii) available data for most technologies; (iii) consistency with other indicators (i.e., not an outlier). The (S3) 'first sequential commercialisation' indicator best meets these criteria. First, it is strongly related to formative innovation processes as the start of commercialization applies knowledge created to intensify production and materialise a technology. Second, data are available for all but one technology. Third, the indicator correlates strongly with the average of the other two indicators ( $r=0.93$ ). The main drawback of the (S3) 'first sequential commercialisation' indicator is that it does not take into account early development and experimentation activities (including the 'incubation time') which might be important formative processes prior to serial production (Markard and Hekkert, 2013; Jacobsson, 2008).

The different indicators for the end point of the formative phase diverge more clearly in some cases (see Figure 3 ). The measures for stationary steam engines, for example, range over a 150 year period from 1727 to 1880 for (E4) 'highest \% cost reduction' and (E1a) '10\% 
cumulative total units' respectively. However, there is less divergence for more recent technologies.

Clear links to theory, available data, and consistency, were again applied as criteria to select a preferred indicator. The (E5) 'user adoption' indicator, measured by a $2.5 \%$ share of market potential being reached, best met the criteria. First, it links directly to the initial segment of market demand identified by Rogers (2003). It is consistent with the formative phase ending since technology risks, uncertainties and market misalignments are reduced such that adoption moves from 'innovators' to the subsequent and larger group of 'early adopters'. Second, data were available for all but one technology (fluid catalytic cracking or FCC in oil refineries). Third, correlations with the average of all the other indicators was high $(r=0.95)$.

To measure this indicator, assumptions have to be made about the potential market within which the innovation is adopted and gains market share. To measure the (E5) 'user adoption' indicator, actual market growth (e.g., units sold or capacity installed) is divided by the potential market size for the corresponding year (see Appendix A). Other methods for inferring thresholds of market take-off compare sales growth rates either with market penetration rates (Tellis et al., 2003), with annual sales (Golder and Tellis, 1997), or with annual net entry rates (Agarwal and Bayus, 2002). Using a 2.5\% share of market potential is comparatively simple, less data demanding, and applies to a broad set of technologies.

One drawback of the 'user adoption' indicator is that it does not directly measure a technology's maturity at the end of the formative phase. The (E2) 'up-scaling of unit size' indicator, measured by a $10 \%$ threshold of maximum unit capacity being reached, was selected as a complementary technology indicator. This conveys important information on the readiness of the technology for commercialisation at larger scales. However, data are only available for those technologies that up-scaled significantly (mainly energy supply technologies). Moreover, the indicator could only be estimated ex post once the unit capacity frontier for each technology had been revealed, unless reliable ex ante estimates could be made based on physical principles. Ex post indicators were suitable for this study of historical technologies in their initial markets for which market saturation is either observed or is being approached.

Of the two preferred indicators, (E5) 'user adoption' generally gives slightly earlier estimates of the end point of the formative phase, up to a decade earlier than the (E2) 'up-scaling' indicator (see Figure 3).

\subsection{Average durations}

Using (S3) 'first sequential commercialisation' and (E5) 'user adoption' as the preferred start and end point indicators respectively, Table 6 shows the central estimates of formative phase duration for each technology. The mean central estimate of formative phase duration 
across the 16 technologies in the sample is 22 years from a range of $4-85$ years. Table 6 also shows the longest estimates of formative phase duration from the earliest start point indicator to the latest end point indicator which vary for each technology. This upper bound on formative phase duration has a mean of 75 years across the technologies in the sample from a range of $4-168$ years.

Table 6. Formative phase durations in years. (Technologies ordered historically by year of invention).

\begin{tabular}{lcc}
\hline Energy technology & $\begin{array}{c}\text { Central } \\
\text { estimate }\end{array}$ & $\begin{array}{c}\text { Longest } \\
\text { estimate }\end{array}$ \\
\hline Stationary Steam Engines & 85 & 168 \\
Steamships & 19 & 114 \\
Steam Locomotives & 21 & 96 \\
Bicycles & 25 & 83 \\
Coal Power & 9 & 79 \\
Natural Gas Power & 25 & 71 \\
Cars & 23 & 82 \\
Washing Machines & 15 & 58 \\
Motorcycles & 21 & 71 \\
Wind Power & 15 & 115 \\
E-Bikes & 35 & 114 \\
Jet Aircraft & 7 & 40 \\
FCC, Fluid Catalytic Cracking (refineries) & 4 & 5 \\
Nuclear Power & 13 & 22 \\
Mobile Phones & 14 & 55 \\
CFLs, Compact Fluorescent Lamps & 20 & 27 \\
\hline Mean (all technologies) & $\mathbf{2 2}$ & $\mathbf{7 5}$ \\
Median (all technologies) & $\mathbf{2 0}$ & $\mathbf{7 5}$ \\
\hline
\end{tabular}

Figure 4 shows the central estimates (dark blue bars) and the longest estimates (light blue bars) of formative phase durations for the technologies ordered historically by year of commercialisation rather than by year of invention, as in Table 6 . This reorders wind power and e-bikes to their later commercial time periods. Three observations can be made. First, formative phase durations for older technologies are more uncertain, particularly in terms of their end points. Second, longer formative phases are more uncertain in duration, which includes those for the steam technologies, passenger cars and natural gas power plants.

Third, even though stationary steam engines passed through a long formative phase in the 18th century, there is no clear trend indicating an acceleration in formative phases for more recent technologies. This result contributes to the debate on accelerated diffusion. Studies of multiple consumer durables show no evidence of a shorter incubation time (Kohli et al., 1999) or of diffusion acceleration over time (Stremersch et al., 2010; Peres et al., 2010). However, Golder and Tellis (1997) find evidence of decreasing time to takeoff of products 
introduced after World War II, and Meade and Islam (2006) similarly discuss studies that suggest an increase of diffusion speed over the past century.

Figure 4. Formative phase durations: central and longest estimates. (Technologies ordered historically by year of commercialization). Note: The origin of the $\mathrm{x}$-axis is set equal to the midpoints of the central estimates for each technology (dark blue bar). Uncertainties in start point are shown to the left of the origin; uncertainties in end point are shown to the right of the origin (light blue bars).

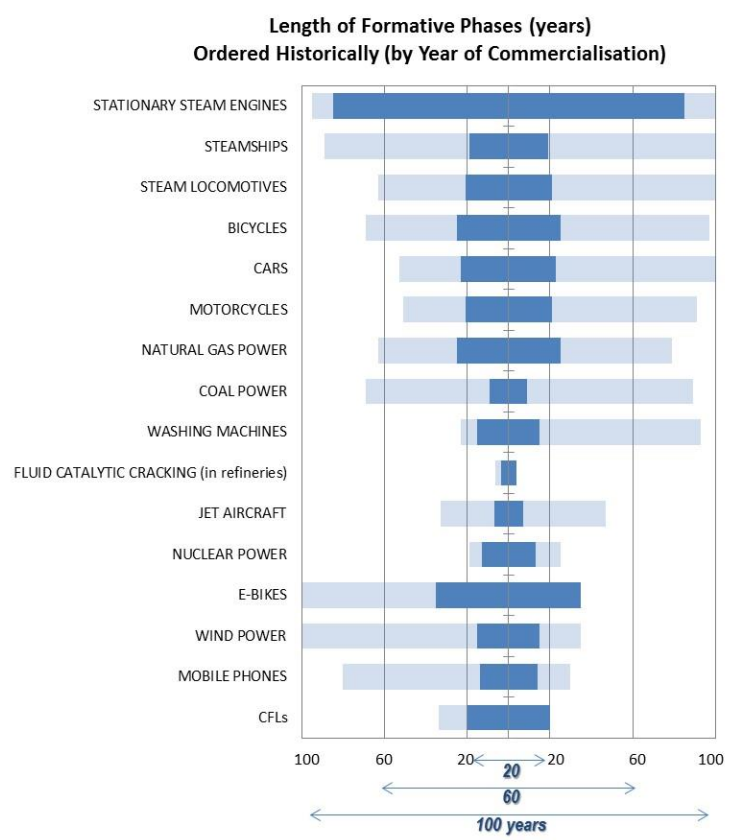

\subsection{Determinants of duration}

Measuring formative phase durations consistently allows a comparative analysis across technologies of the effect of technology and market characteristics. Although the innovation systems literature identifies key formative processes, it does not generalise how long these processes tend to last nor what the determinants of formative phase duration may be.

In contrast, the factors that explain the duration of diffusion are more clearly understood. These include: relative advantage, complexity, compatibility (Rogers, 2003; Golder and Tellis, 1997; Fabrizio and Hawn, 2013); substitutability, inter-relatedness and infrastructure needs (Grubler et al., 1999); and market size (Wilson et al., 2012).

By signalling important characteristics of the technology and market, similar factors may affect the duration of formative phases as well. For example, technologies which are not ready substitutes for incumbent technologies may require longer formative phases to align supporting institutions (legitimation) and to stimulate user demand in forming markets (Hekkert et al., 2007). Other factors explaining formative phase duration may include unit scale, which affects the risks and resource requirements for experimentation with multiple units, and the up-scaling of unit sizes, which is associated with convergence on a dominant 
design and a clearly articulated market demand. Figure 5 presents formative phase durations sorted by these three factors: substitutability, unit scale and up-scaling.

Figure 5. Formative phase durations in years, ordered by substitutability (left panel), by unit scale (middle panel) and up-scaling (right panel).
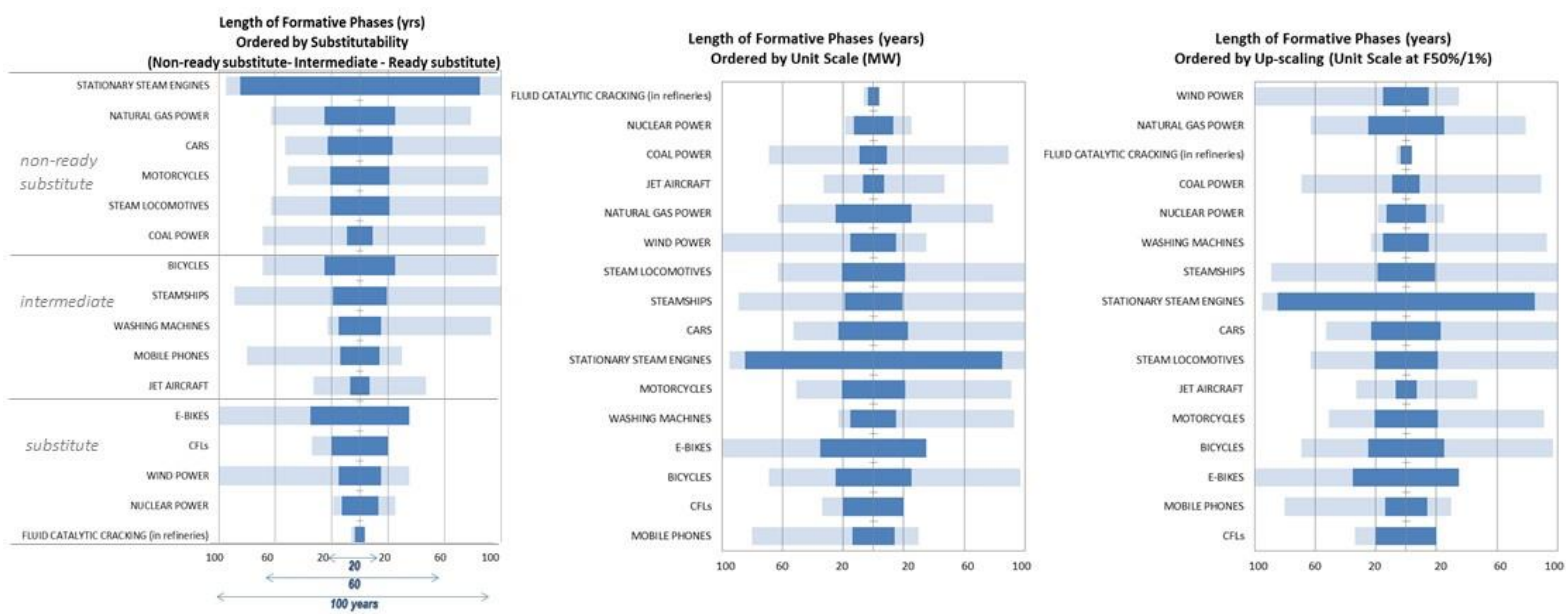

\section{a) Substitutability}

Technologies in the sample vary in the extent to which they are ready substitutes for incumbent technologies. Diffusion processes are slower for non-ready substitutes that need new institutions and infrastructures to develop to enable commercialisation (Grubler et al., 1999). The potential to share structural elements with other innovation systems may also be more limited for technologies that are not ready substitutes. This constrains the positive externalities which enable more rapid innovation system development (Bergek et al., 2008b, 2015).

As an approximation of substitutability, the 16 energy technologies in the sample were subjectively assigned to one of three categories (non-ready substitutes, intermediate, ready substitutes) based on the extent to which their market deployment depended on demand for novel services and changes in user practices, or new infrastructures and supporting institutions. As examples, steam engines brought new energy services in mines and industry (non-ready substitute), whereas wind power diffused into already existing electricity networks and markets (ready substitute).

Figure 5 (left panel) indicates relatively rapid formative phases in the case of ready substitute technologies for which ancillary infrastructure (airports, electricity grids, refuelling stations, etc.) was already in place. Non-ready substitute technologies, including stationary steam engines, passenger cars, coal and gas power, needed longer to develop the requisite knowledge, institutional capacity and infrastructure to mature commercially and scale up. 


\section{b) Unit scale}

Figure 5 (middle panel) shows formative phase durations ordered by unit scale (in MW) with larger sized technologies at the top. Although no overall pattern is observed, very large technologies including fluid catalytic cracking, nuclear power plants and jet aircraft, show relatively rapid formative phases. This result is unexpected considering the significant challenges, resource requirements, and risks involved in the deployment of these large-scale technologies. However, the formative phases of all three technologies were linked to the unique institutional environment around World War II, including strong demand-pull, price insensitive military users, and sharing of intellectual property (Delina and Diesendorf, 2013). This raises the possibility that formative phases can be compressed or accelerated in extreme demand environments with simultaneous market-pull and technology-push efforts, and low sensitivity to risk.

\section{c) Up-scaling}

Figure 5 (right panel) shows formative phase durations ordered by up-scaling of unit sizes, with larger up-scaled technologies at the top. Up-scaling is measured by the growth in unit size up until the midpoint of the diffusion curve. There is no clearly observable relationship between up-scaling and formative phase duration. Some technologies that barely scaled up had long formative phases (e.g., washing machines); others that up-scaled intensively passed through a fast period of formation (e.g., nuclear power).

\section{d) Other determinants}

Table 7 summarises the formative phase durations for subsets of technologies grouped by substitutability, unit size, and up-scaling. Differences in the mean formative phase durations between groups were tested for significance, using an $80 \%$ confidence interval appropriate for small heterogeneous samples (Boland et al, 2001). Tests confirm the patterns observed in Figure 5, especially for ready substitute technologies which have significantly shorter formative phases. However, given the small sample, wide confidence intervals, and the subjective classification of substitutability, results at this stage are considered to be indicative only.

Technologies are also grouped according to their applications: energy supply vs. end-use; transport vs. non-transport; and environmental vs. non-environmental technologies. Enduse technologies might be expected to have shorter formative phases if their smaller unit sizes allow more rapid learning cycles, whereas transport technologies and environmental technologies might be expected to have longer formative phases if their commercialisation is strongly dependent on dedicated infrastructure or regulation respectively. Tests of difference shown in Table 7 support these expectations only in the case of environmental technologies. Other differences were found to be not significant, even if the direction of difference was consistent with expectations. 
Table 7. Determinants of formative phase duration. Notes: means show average durations per subset of technologies using central estimates for each technology. Significance of t-test statistics use $80 \%$ confidence intervals (see text for details).

\begin{tabular}{|c|c|c|c|c|}
\hline Technology or market characteristic & $\begin{array}{l}\text { Number of } \\
\text { technologies } \\
\text { (n) }\end{array}$ & $\begin{array}{c}\text { Mean formative } \\
\text { phase duration } \\
\text { (years) }\end{array}$ & Expectation & Result \\
\hline \multicolumn{5}{|l|}{ Technology characteristics } \\
\hline Substitutability & & & shorter for & \multirow{4}{*}{$\begin{array}{l}\text { expectation } \\
\text { supported }\end{array}$} \\
\hline Non-Ready Substitute & 6 & 31 & substitute & \\
\hline \multirow[t]{2}{*}{ Ready Substitute } & 5 & 17 & technologies & \\
\hline & & $t=1.09$ * & & \\
\hline \multicolumn{5}{|l|}{ Unit scale } \\
\hline Above $1 \mathrm{MW}$ & 12 & 22 & shorter for small & expectation \\
\hline \multirow[t]{2}{*}{ Below $1 \mathrm{MW}$} & 4 & 24 & & \\
\hline & & $t=.28$ & & \\
\hline Up-scaling & & & \multirow{3}{*}{$\begin{array}{l}\text { shorter for low up- } \\
\text { scaling }\end{array}$} & \multirow{4}{*}{$\begin{array}{c}\text { expectation } \\
\text { confounded } \\
\text { (opposite result) }\end{array}$} \\
\hline High (higher than $5 x$ ) & 5 & 13 & & \\
\hline \multirow[t]{2}{*}{ low (less than $1 \mathrm{x}$ ) } & 4 & 24 & & \\
\hline & & $t=1.82 * *$ & & \\
\hline \multicolumn{5}{|l|}{ Initial cost } \\
\hline High (more than $\$ 1,000$ ) & 3 & 42 & $\begin{array}{l}\text { snorter tor lower } \\
\text { initial cost }\end{array}$ & $\begin{array}{l}\text { expectation } \\
\text { not supported }\end{array}$ \\
\hline \multirow[t]{2}{*}{ Low (less than $\$ 1,000)$} & 4 & 25 & & \\
\hline & & $t=.71$ & & \\
\hline \multicolumn{5}{|l|}{ Technology lifetime } \\
\hline Long (equal or more than 20 years) & 9 & 22 & shorter for shorter & expectation \\
\hline \multirow[t]{2}{*}{ Short (less than 20 years) } & 7 & 22 & lifetime & not supported \\
\hline & & $t=.01$ & & \\
\hline \multicolumn{5}{|l|}{ Application of technology } \\
\hline End-use & 10 & 20 & shorter for end-use & expectation \\
\hline \multirow[t]{2}{*}{ Supply } & 6 & 25 & technologies & not supported \\
\hline & & $t=.41$ & & \\
\hline Transport & 7 & 22 & shorter for other & expectation \\
\hline \multirow[t]{2}{*}{ Non-Transport } & 9 & 22 & technologies & not supported \\
\hline & & $t=.07$ & & \\
\hline Environmental & 4 & 24 & shorter for other & expectation \\
\hline \multirow[t]{2}{*}{ Non-Environmental } & 6 & 15 & technologies & supported \\
\hline & & $t=1.57 * *$ & & \\
\hline \multicolumn{5}{|l|}{ Diffusion characteristics } \\
\hline \multicolumn{5}{|l|}{ Diffusion duration } \\
\hline Very slow (more than 50 years) & 7 & 30 & shorter for rapid & expectation \\
\hline \multirow[t]{2}{*}{ Rapid (20 years or less) } & 5 & 19 & diffusion & supported \\
\hline & & $t=1.03 *$ & & \\
\hline \multicolumn{3}{|l|}{ Diffusion pervasiveness } & & expectation \\
\hline High (more than $10,000 \mathrm{MW}$ ) & 6 & 15 & $\begin{array}{l}\text { Snorter tor lower } \\
\text { pervasiveness }\end{array}$ & confounded \\
\hline Low (less than 10,000 MW) & 10 & 26 & & (opposite result) \\
\hline & & $t=1.41 * *$ & & \\
\hline
\end{tabular}

* significant at 0.2 level, ${ }^{* *}$ significant at 0.1 level, ${ }^{* * *}$ significant at 0.05 level. a Environmental technologies comprise CFLs, e-bikes, bicycles, and wind power; non-environmental technologies include jet aircrafts, motorcycles, cars, refineries, coal power, and gas power. 
Table 7 also includes tests for other potential determinants of formative phase duration. All else being equal, longer formative phases might be expected for technologies that diffuse more pervasively, have higher initial costs and longer lifetimes. These latter two characteristics imply fewer or more costly opportunities for rapid experimentation and learning cycles during the formative phase.

More rapid formative phases were found for technologies with pervasive impacts in the market. These unexpected results which confounded expectations are again influenced by the presence in these two subsets of technologies of nuclear power and fluid catalytic cracking linked to accelerated formation during a time of war. In sum, the results show that certain technology characteristics, technology applications and overall diffusion can have an effect in the duration of formative phases.

\section{Discussion and conclusion}

The objective of this research was to develop an operational definition of the duration of formative phases to enable comparative technology analysis. The formative phase designates the early stage of technology development that prepares an innovation for upscaling and widespread growth. It was shown that a set of indicators can be developed from signs of innovation maturity and formative processes identified in the literature and then be consistently applied to a diverse sample of technologies.

The year of first sequential commercialization is a decisive mark at the start of the formative phase by showing the innovation's readiness to fulfil expectations of initial demand. Distinguishing a clear end point for the formative phase is more uncertain. Diffusion passing an adoption threshold of $2.5 \%$ of its market potential is an important milestone as it coincides with the adoption of a new technology by risk-taking "innovators" whose user experiences contribute to lowering perceived risks and aligning the technology with market needs (Rogers, 2003). For a subset of technologies that up-scale, a $10 \%$ threshold of the unit capacity frontier being reached is a complementary metric of a maturing technology that correlates well with the user adoption metric.

Applying these start and end point indicators to a sample of 16 energy technologies shows that formative phases are long, lasting on average over 20 years. Establishing a functioning innovation system to support a technology's diffusion takes time. Formative phase durations are significantly longer for technologies that are not ready substitutes and that provide novel energy services. Steam engines are the clearest example. Crude and expensive initial designs required lengthy cycles of knowledge creation, testing and refinement to address uncertainties on designs, markets, and applications (Craft, 2004). Other technologies that created new service demands and markets, including cars and coal power from the early $20^{\text {th }}$ century, require not just an extended period of experimentation and knowledge 
development, but also an extensive institutional process of legitimation to overcome the "liability of newness" (Bergek et al., 2008a).

More generally, institutional context was found to be decisive in the formation of new technologies. The sample comprised a set of complex, large-scale technologies, including nuclear power and jet aircraft, whose formative phases were compressed due to aggressive innovation efforts combining market-pull and technology-push under the extreme environment of WWII (Delina \& Diesendorf, 2013). This reinforces the importance of understanding the role of contextual influences in TIS development (Bergek et al., 2015).

There were few other consistent influences of market and technology characteristics on formative phase durations. Expectations that smaller unit scale, less cost intensive, energy end-use technologies might have shorter formative phases given the more numerous opportunities for experimentation and learning were not supported in the data. The only significant determinants of relatively rapid formative phases in line with expectations were substitute technologies with short market diffusion times and non-environmental technologies. Given the small size of the data set, this latter finding needs further research to test how regulation or policy can support environmental technologies as part of broader system transitions.

However, the central finding of formative phases averaging over two decades in duration corroborates the importance of accumulative processes identified in the innovation systems literature, including experimentation in the initial years of the formative phase, as well as legitimation and market formation at a later stage (Bergek et al. 2008a; Markard and Hekkert, 2013).

This highlights the risks inherent in current efforts to accelerate the commercialisation of low carbon technologies (Winskel and Radcliffe, 2014; Henderson and Newell, 2011). The stringency of climate change mitigation targets has led to calls to compress the formative phases of a wide portfolio of novel energy supply and end-use technologies from carbon capture and storage (Haszeldine 2009) and next generation nuclear power (Grimes and Nuttall, 2010) to cellulosic biofuels and electric vehicles (Tran et al., 2012).

The historical evidence analysed in this research shows that compressed formative phases are only characteristic of technologies that are ready substitutes for incumbents (e.g. compact fluorescent lamps, wind power). Centralised low carbon power production and hybrid-electric vehicles meet these criteria for rapid formation more closely than carbon capture and storage (CCS) with its requirements for new $\mathrm{CO}_{2}$ pipeline infrastructure (Smil 2010) or electric vehicles with their requirements for reshaped user expectations and driving practices (Tran et al. 2012). As CCS systems at industrial scales have not been sequentially commercialised over two or more years (de Coninck and Benson, 2014), it is even arguable whether CCS has yet begun its formative phase. 
History thus offers a cautionary note on the potentials and risks of policy efforts to accelerate formative phases. Policies pushing to commercialise pre-mature technologies by picking a technical design or shortcutting key formative processes can result in failure. Examples from the early 1980 s include the breeder reactor and synfuel production in the US, and the rapid up-scaling of wind turbines in Germany and the Netherlands (Grubler and Wilson, 2014). A systemic and sustained approach to technology formation, supported by stable and consistent policy, is more likely to help accumulate knowledge and experience from experimentation while building and aligning market demand.

There are various fruitful avenues for further research. First, results can be validated on a larger sample of technologies and additional indicators can be used to track the start and end points of formative phases (e.g., number of patent applications, dominant designs, R\&D expenditures). Data availability may be an issue in both cases. Second, further testing is needed to detect robust explanations of formative phase durations across diverse technologies, particularly for those factors where results confounded expectations (e.g., upscaling, diffusion pervasiveness). Multivariate models controlling for other influences may be possible for larger samples. Third, it would be interesting to explore whether shorter formative phases are more strongly associated with lock-in to a dominant design that ultimately proves inferior, as has been argued for technologies such as the pressurised water reactor in the nuclear industry (Cowan, 1990). Finally, the characteristics of formative phases for innovations that failed to diffuse in the market should also be examined.

\section{Acknowledgments}

The research on which this article is based was supported by a grant from the International Institute for Applied Systems Analysis (IIASA), and Harvard Kennedy School. The authors would also like to thank Arnulf Grübler for valuable insights throughout the research, as well as Henry Lee, Laura Diaz Anadon and Luís Cabral.

\section{Supplementary material}

The spreadsheets containing the data series and all the analysis can be found at http://webarchive.iiasa.ac.at/ bento 
Appendix A. Data compiled for 16 energy technologies. (Technologies ordered historically by year of invention). See Appendices $B$ and $C$ for details.

\begin{tabular}{|c|c|c|c|c|c|c|c|c|}
\hline \multirow{2}{*}{\multicolumn{2}{|c|}{ Technology * }} & \multirow{3}{*}{$\begin{array}{c}\text { Data \& Units } \\
\begin{array}{c}\text { Total Capacity } \\
(\#, h p)\end{array}\end{array}$} & \multicolumn{3}{|c|}{ Time Series } & \multirow{2}{*}{$\begin{array}{c}\text { Initial Markets } \\
\text { (scale of } \\
\text { analysis) }\end{array}$} & \multirow{2}{*}{$\begin{array}{c}\text { Market Potential } \\
\qquad * *\end{array}$} & \multirow[b]{2}{*}{ Main Sources } \\
\hline & & & Unit Capacity & $\begin{array}{c}\text { Unit } \\
\text { Numbers }\end{array}$ & $\begin{array}{l}\text { Industry } \\
\text { Capacity }\end{array}$ & & & \\
\hline $\begin{array}{c}\text { Stationary } \\
\text { Steam } \\
\text { Engines }\end{array}$ & Su & & $\mid \begin{array}{c}1710-1930 \\
\text { (average only) }\end{array}$ & $1710-1930$ & $1710-1930$ & UK, US & $\begin{array}{c}\text { power provided } \\
\text { by different } \\
\text { sources }\end{array}$ & $\begin{array}{c}\text { Kanefsky, } \\
\text { Woytinsky, US } \\
\text { Census }\end{array}$ \\
\hline Steamships & Ed & $\begin{array}{l}\text { Installed } \\
\text { Capacity } \\
(\#, \mathrm{hp})\end{array}$ & $\begin{array}{c}1810-1940 \\
\text { (average only) }\end{array}$ & 1810-1940 & $1810-1940$ & UK, US & $\begin{array}{l}\text { gross tonnage of } \\
\text { merchant vessel } \\
\text { fleet (sail, steam, } \\
\text { motor) }\end{array}$ & $\begin{array}{c}\text { Mitchell, } \\
\text { Woytinsky, US } \\
\text { Census }\end{array}$ \\
\hline $\begin{array}{c}\text { Steam } \\
\text { Locomotives }\end{array}$ & Ed & $\begin{array}{l}\text { Installed } \\
\text { Capacity } \\
(\#, \mathrm{hp})\end{array}$ & $\begin{array}{c}1830-1960 \\
\text { (average only) }\end{array}$ & $1830-1960$ & 1830-1960 & UK, US & $\begin{array}{l}\text { rail passenger } \\
\text { traffic (million } \\
\text { passengers) }\end{array}$ & $\begin{array}{c}\text { Woytinsky, US } \\
\text { Census, } \\
\text { Daugherty }\end{array}$ \\
\hline Bicycles & Ed & Production(\#) & estimated & $1861-2010$ & estimated & $\begin{array}{l}\text { UK, France, } \\
\text { Germany }\end{array}$ & population & $\begin{array}{l}\text { UN, UK and } \\
\text { US Census, } \\
\text { INSEE, DIW }\end{array}$ \\
\hline Coal Power & Su & $\begin{array}{l}\text { Capacity } \\
\text { Additions } \\
(\#, \mathrm{MW})\end{array}$ & $\begin{array}{l}\text { 1908-2000 } \\
\text { (max. \& } \\
\text { average) }\end{array}$ & $1908-2000$ & $1908-2000$ & OECD & $\begin{array}{c}\text { number of } \\
\text { power plants in } \\
\text { use }\end{array}$ & Platts \\
\hline $\begin{array}{c}\text { Natural Gas } \\
\text { Power }\end{array}$ & Su & $\begin{array}{l}\text { Capacity } \\
\text { Additions } \\
(\#, \mathrm{MW})\end{array}$ & $\begin{array}{l}\text { 1903-2000 } \\
\text { (max. \& } \\
\text { average) }\end{array}$ & $1903-2000$ & $1903-2000$ & OECD & $\begin{array}{c}\text { number of } \\
\text { power plants in } \\
\text { use }\end{array}$ & Platts \\
\hline $\begin{array}{c}\text { Passenger } \\
\text { Cars }\end{array}$ & Ed & $\begin{array}{l}\text { Production (\#) } \\
\text { \& Engine } \\
\text { Capacity (hp) }\end{array}$ & $\begin{array}{l}1910-1960 \\
1960-2005\end{array}$ & $1900-2005$ & $\begin{array}{l}\text { calculated } \\
\text { from unit } \\
\text { data }\end{array}$ & US & $\begin{array}{l}\text { number of } \\
\text { households }\end{array}$ & $\begin{array}{c}\text { AAMA, US } \\
\text { NHTSA, ACEA }\end{array}$ \\
\hline $\begin{array}{l}\text { Washing } \\
\text { Machines }\end{array}$ & Ed & $\begin{array}{l}\text { Production } \\
\text { (\#) }\end{array}$ & estimated & $1920-2008$ & estimated & US & $\begin{array}{l}\text { number of } \\
\text { households }\end{array}$ & $\begin{array}{l}\text { UN, Stiftung } \\
\text { Warentest }\end{array}$ \\
\hline Motorcycles & Ed & $\begin{array}{l}\text { Production } \\
\text { (\#) }\end{array}$ & estimated & $1900-2008$ & $1900-2008$ & $\begin{array}{l}\text { UK, France, } \\
\text { Germany, Italy }\end{array}$ & $\begin{array}{l}\text { number of } \\
\text { households }\end{array}$ & UN \\
\hline Wind Power & Su & $\begin{array}{c}\text { Capacity } \\
\text { Additions } \\
(\#, \mathrm{MW}) \\
\end{array}$ & $\begin{array}{c}1977-2008 \\
\text { (average only) }\end{array}$ & 1977-2008 & 1977-2008 & Denmark & $\begin{array}{c}\text { electricity } \\
\text { generation mix }\end{array}$ & $\begin{array}{l}\text { DEA, BTM } \\
\text { Consult }\end{array}$ \\
\hline $\begin{array}{l}\text { Electric } \\
\text { Bicycles } \\
\text { (E-bikes) }\end{array}$ & $\mathrm{Ed}$ & Production (\#) & estimated & 1997-2010 & estimated & China & $\begin{array}{l}\text { number of } \\
\text { households }\end{array}$ & $\begin{array}{c}\text { Weinert, } \\
\text { Jamerson \& } \\
\text { Benjamin }\end{array}$ \\
\hline $\begin{array}{l}\text { Passenger } \\
\text { Jet Aircraft }\end{array}$ & Ed & $\begin{array}{l}\text { Production (\#, } \\
\text { Model) \& } \\
\text { Engine Thrust } \\
\text { (kN) }\end{array}$ & $\begin{array}{l}\text { 1958-2007 } \\
\text { (max. \& } \\
\text { average) }\end{array}$ & $1958-2007$ & $1958-2007$ & Boeing & $\begin{array}{c}\text { number of air } \\
\text { carriers in service }\end{array}$ & $\begin{array}{c}\text { Jane's, aircraft } \\
\text { databases }\end{array}$ \\
\hline $\begin{array}{c}\text { Fluid } \\
\text { Catalytic } \\
\text { Cracking } \\
\text { (FCC) in Oil } \\
\text { Refineries } \\
\end{array}$ & Su & $\begin{array}{l}\text { Total Capacity } \\
\text { (bpd) }\end{array}$ & $\begin{array}{c}1940-2000 \\
\text { (average only) }\end{array}$ & $\begin{array}{c}\text { not } \\
\text { available }\end{array}$ & 1940-2007 & $\begin{array}{c}\text { OECD, } \\
\text { Former Soviet } \\
\text { Union (FSU) }\end{array}$ & - & $\begin{array}{c}\text { Oil \& Gas } \\
\text { Journal, BP, } \\
\text { Enos }\end{array}$ \\
\hline $\begin{array}{l}\text { Nuclear } \\
\text { Power }\end{array}$ & $\mathrm{Su}$ & $\begin{array}{l}\text { Capacity } \\
\text { Additions } \\
(\#, \mathrm{MW})\end{array}$ & $\begin{array}{l}\text { 1956-2000 } \\
\text { (max. \& } \\
\text { average) }\end{array}$ & $1956-2000$ & $1956-2000$ & OECD & $\begin{array}{l}\text { total installed } \\
\text { capacity }\end{array}$ & Platts \\
\hline $\begin{array}{l}\text { Mobile } \\
\text { Phones }\end{array}$ & $\mathrm{Ed}$ & $\begin{array}{l}\text { Sales } \\
(\#) \\
\end{array}$ & estimated & 1979-2010 & 1979-2010 & $\begin{array}{c}\text { Scandinavia, } \\
\text { Japan }\end{array}$ & population & Gartner \\
\hline $\begin{array}{c}\text { Compact } \\
\text { Fluorescent } \\
\text { Light Bulbs } \\
\text { (CFLs) }\end{array}$ & Ed & $\begin{array}{l}\text { Sales } \\
(\#)\end{array}$ & estimated & 1990-2003 & estimated & $\begin{array}{l}\text { OECD (exc. } \\
\text { Japan) }\end{array}$ & light bulb sales & IEA \\
\hline
\end{tabular}

* Su = energy supply technologies, $\mathrm{Ed}=$ end-use technologies.

** Market potential used for end point indicator (see text for details). Data for same initial markets as time series, except for: stationary steam engines (UK); jet aircraft (US); steamships (US); motorcycles (UK). 


\section{Appendix B. Start of formative phase: Data synthesis}

\begin{tabular}{|c|c|c|c|c|c|c|c|c|c|c|c|c|c|c|c|c|c|c|}
\hline $\begin{array}{l}\text { Formative } \\
\text { Phase }\end{array}$ & INDICATOR & UNITS & $\begin{array}{l}\text { STATIONARY } \\
\text { STEAM } \\
\text { ENGINES }\end{array}$ & STEAMSHIPS & $\begin{array}{c}\text { STEAM } \\
\text { LOCOMOTIVES }\end{array}$ & BICYCLES & $\begin{array}{l}\text { WIND } \\
\text { POWER }\end{array}$ & $\begin{array}{c}\text { COAL } \\
\text { POWER }\end{array}$ & MOTORCYCLES & CARS & E-BIKES & $\begin{array}{c}\text { NATURAL } \\
\text { GAS } \\
\text { POWER }\end{array}$ & $\begin{array}{l}\text { WASHING } \\
\text { MACHINES }\end{array}$ & CFLS & $\begin{array}{c}\text { FLUID } \\
\text { CATALYTIC } \\
\text { CRACKIIG (in } \\
\text { refineries) }\end{array}$ & $\begin{array}{c}\text { JET } \\
\text { AIRCRAFT }\end{array}$ & $\begin{array}{l}\text { NUCLEAR } \\
\text { POWER }\end{array}$ & $\begin{array}{l}\text { MOBLIE } \\
\text { PHONES }\end{array}$ \\
\hline \multirow[t]{2}{*}{$\begin{array}{l}\text { Reference } \\
\text { Points }\end{array}$} & $\begin{array}{l}\text { Invention (cf. } \\
\text { invention lists) }\end{array}$ & Year & 1707 & 1707 & 1769 & 1818 & 1888 & 1842 & 1885 & 1860 & 1897 & 1842 & 1884 & 1972 & 1929 & 1928 & 1943 & 1973 \\
\hline & & Source & $\begin{array}{l}\text { Haustein \& } \\
\text { Neuwirth }\end{array}$ & $\begin{array}{l}\text { Haustein \& } \\
\text { Neuwirth }\end{array}$ & Mensch & Mensch & Gipe & Mensch & Van Duijn & Mensch & $\begin{array}{c}\text { US } \\
\text { Patent } \\
596,272\end{array}$ & Mensch & Van Duijn & $\begin{array}{l}\text { IEA } \\
(2006)\end{array}$ & Enos (1962) & Mensch & $\begin{array}{l}\text { Haustein \& } \\
\text { Neuwirth }\end{array}$ & $\begin{array}{l}\text { US Patent } \\
3,906,166\end{array}$ \\
\hline \multirow[t]{9}{*}{$\begin{array}{l}\text { Ex Ante } \\
\text { START } \\
\text { POINTS }\end{array}$} & $\begin{array}{l}\text { First } \\
\text { 'embodiment' of } \\
\text { technology }\end{array}$ & Year & 1712 & 1776 & 1804 & $n / d$ & 1887 & 1878 & 1885 & 1873 & 1891 & $n / d$ & 1904 & 1973 & 1940 & $n / d$ & 1951 & 1946 \\
\hline & & Model & Newcomen & $\begin{array}{l}\text { Jouffroi's } \\
\text { Palmipède }\end{array}$ & $\begin{array}{l}\text { Trevithick's } \\
\text { locomotive }\end{array}$ & $n / d$ & $\begin{array}{c}\text { First } \\
\text { wind } \\
\text { turbine }\end{array}$ & $\begin{array}{c}\text { First } \\
\text { power } \\
\text { station in } \\
\text { Bavaria } \\
\end{array}$ & $\begin{array}{l}\text { Daimler- } \\
\text { Maybach's } \\
\text { Reitwagen }\end{array}$ & $\begin{array}{l}\text { Bollé's 1st } \\
\text { steam } \\
\text { vehicle }\end{array}$ & $\begin{array}{l}\text { Electric } \\
\text { tricycle } \\
\text { by A.L. } \\
\text { Ryker } \\
\end{array}$ & $n / d$ & $\begin{array}{c}\text { First } \\
\text { electric } \\
\text { washing } \\
\text { machine } \\
\end{array}$ & $\begin{array}{c}\text { GE } \\
\text { invents } \\
\text { spiral } \\
\text { CFL } \\
\end{array}$ & $\begin{array}{l}\text { Pilot plant } \\
\text { in Louisiana }\end{array}$ & $n / d$ & EBR-I Idaho & $\begin{array}{l}\text { First mobile } \\
\text { phone in a } \\
\text { car }\end{array}$ \\
\hline & $\begin{array}{l}\text { First application } \\
\text { outside lab / } \\
\text { commercial } \\
\text { application (I) }\end{array}$ & Year & 1712 & 1809 & 1824 & 1839 & 1891 & 1884 & 1894 & 1886 & $n / d$ & 1884 & 1907 & 1980 & 1942 & 1941 & 1954 & $n / d$ \\
\hline & & (innov.list) & $\begin{array}{c}\text { Von } \\
\text { Tunzelmann } \\
(1978)\end{array}$ & $\begin{array}{c}\text { Silverberg \& } \\
\text { Verspagen; } \\
\text { Haustein \& } \\
\text { Neuwirth }\end{array}$ & Mensch & Mensch & Gipe & Mensch & $\begin{array}{l}\text { Silverberg \& } \\
\text { Verspagen; } \\
\text { Van Duijn }\end{array}$ & Mensch & $n / d$ & Mensch & $\begin{array}{c}\text { Silverberg } \\
\quad \& \\
\text { Verspagen; } \\
\text { Van Duijn } \\
\end{array}$ & $\begin{array}{c}\text { IEA } \\
(2006)\end{array}$ & $\begin{array}{l}\text { Silverberg \& } \\
\text { Verspagen }\end{array}$ & Mensch & $\begin{array}{c}\text { Silverberg } \\
\text { \&Verspagen; } \\
\text { Haustein } \\
\text { \&Neuwirth }\end{array}$ & $n / d$ \\
\hline & $\begin{array}{l}\text { First application } \\
\text { outside lab / } \\
\text { commercial } \\
\text { application (II) }\end{array}$ & Year & 1712 & 1807 & 1814 & 1861 & 1891 & 1882 & 1894 & 1885 & $n / d$ & $n / d$ & $\begin{array}{ll}1908 \\
\end{array}$ & 1980 & 1942 & 1939 & 1954 & 1977 \\
\hline & & $\begin{array}{c}\text { Own } \\
\text { Research }\end{array}$ & Newcomen & $\begin{array}{l}\text { Robert } \\
\text { Fulton's } \\
\text { Clermont }\end{array}$ & $\begin{array}{l}\text { Stephenson's } \\
\text { Locomotion }\end{array}$ & $\begin{array}{l}\text { Michaux's } \\
\text { Velocipède }\end{array}$ & La Cour & $\begin{array}{c}\text { Edison } \\
\text { Electric } \\
\text { Light } \\
\text { Station } \\
\end{array}$ & $\begin{array}{c}\text { H\&W } \\
\text { motorcycles }\end{array}$ & Benz & $n / d$ & $n / d$ & $\begin{array}{l}\text { Thor } \\
\text { washer }\end{array}$ & $\begin{array}{c}\text { Philips } \\
\text { model } \\
\text { SL }\end{array}$ & Enos (1962) & $\begin{array}{l}\text { von } \\
\text { Ohain's } \\
\text { first flight }\end{array}$ & $\begin{array}{c}\text { USSR's } \\
\text { Obninsk } \\
\text { plant }\end{array}$ & $\begin{array}{l}\text { Prototype } \\
\text { cellular } \\
\text { system }\end{array}$ \\
\hline & $\begin{array}{l}\text { First sequential } \\
\text { commercialization }\end{array}$ & Year & 1717 & 1811 & 1825 & 1861 & 1977 & $\begin{array}{ll}1908 \\
\end{array}$ & 1900 & 1888 & 1970 & 1903 & 1908 & 1980 & $n / d$ & 1952 & 1954 & 1979 \\
\hline & & $\begin{array}{c}\text { Number of } \\
\text { Units }\end{array}$ & 5 & 1 & 4 & 2 & 2 & 1 & 1330 & $n / d$ & $n / d$ & 1 & $n / d$ & 100000 & $n / d$ & 10 & 1 & $n / d$ \\
\hline & & Model & Newcomen & $\begin{array}{l}\text { Paddle wheel } \\
\text { and sail }\end{array}$ & $\begin{array}{c}\text { Locomotion No } \\
1\end{array}$ & $\begin{array}{l}\text { Michaux's } \\
\text { Velocipède }\end{array}$ & $\begin{array}{l}\text { Danish } \\
\text { 3-blade } \\
\text { (26kW) }\end{array}$ & $\begin{array}{c}\text { Turbo } \\
\text { generators }\end{array}$ & Werner (UK) & Benz car & $n / d$ & $n / d$ & Thor & $\begin{array}{l}\text { Philips } \\
\text { SL }\end{array}$ & $n / d$ & Comet & $\begin{array}{c}\text { APS-1 } \\
\text { OBNINSK }\end{array}$ & $\begin{array}{c}\text { First } \\
\text { commercial } \\
\text { system in } \\
\text { Japan }\end{array}$ \\
\hline \multirow[t]{2}{*}{$\begin{array}{l}\text { Additional } \\
\text { Indicators }\end{array}$} & $\begin{array}{l}\text { First maximum in } \\
\text { public R\&D } \\
\text { expenditure }\end{array}$ & Year & $n / d$ & $n / d$ & $n / d$ & $n / d$ & $n / d$ & $n / d$ & $n / d$ & $n / d$ & $n / d$ & $n / d$ & $n / d$ & $n / d$ & $n / d$ & 1971 & 1983 & 1987 \\
\hline & & $\begin{array}{l}\text { Public } \\
\text { R\&D in } \\
2005 \$ \\
\text { million }\end{array}$ & $n / d$ & $n / d$ & $n / d$ & $n / d$ & $n / d$ & $n / d$ & $n / d$ & $n / d$ & $n / d$ & $n / d$ & $n / d$ & $n / d$ & $n / d$ & 11185 & 3963 & 15726 \\
\hline
\end{tabular}

Legend: $n / d$ (no data), not applicable (n/a)

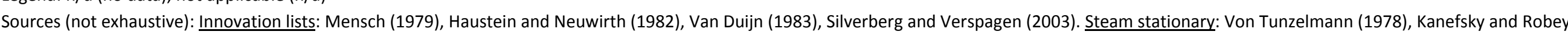

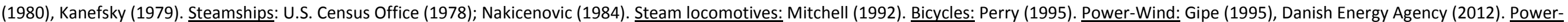

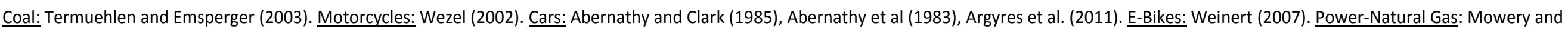

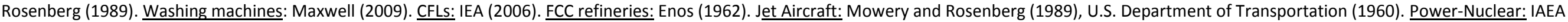
(2012). Cellphones: National Science Foundation (2012). For more details on the data see Bento and Wilson (2014). 


\section{Appendix C. End of formative phase: Data synthesis}

\begin{tabular}{|c|c|c|c|c|c|c|c|c|c|c|c|c|c|c|c|c|c|c|}
\hline $\begin{array}{l}\text { Formative } \\
\text { Phase }\end{array}$ & INDICATOR & UNITS & $\begin{array}{l}\text { STATIONARY } \\
\text { STEAM } \\
\text { ENGINES }\end{array}$ & STEAMSHIPS & $\begin{array}{c}\text { STEAM } \\
\text { LOCOMOTIVES }\end{array}$ & BICYCLES & $\begin{array}{l}\text { WIND } \\
\text { POWER }\end{array}$ & $\begin{array}{l}\text { COAL } \\
\text { POWER }\end{array}$ & MOTORCYCLES & CARS & E-BIKES & $\begin{array}{l}\text { NATURAL } \\
\text { GAS POWER }\end{array}$ & $\begin{array}{l}\text { WASHING } \\
\text { MACHINES }\end{array}$ & CFLS & $\begin{array}{c}\text { FLUID } \\
\text { CATALYTIC } \\
\text { CRACKING } \\
\text { (in } \\
\text { refineries) } \\
\end{array}$ & $\begin{array}{c}\text { JET } \\
\text { AIRCRAFT }\end{array}$ & $\begin{array}{l}\text { NUCLEAR } \\
\text { POWER }\end{array}$ & $\begin{array}{l}\text { MOBILE } \\
\text { PHONES }\end{array}$ \\
\hline \multirow{3}{*}{$\begin{array}{l}\text { Ex Post } \\
\text { END } \\
\text { POINTS }\end{array}$} & $\begin{array}{l}\text { Fraction of } \\
\text { full }\end{array}$ & Year of $10 \% \mathrm{~K}$ (cumul.\#) & 1870 & 1880 & 1880 & 1922 & 1985 & 1938 & 1949 & 1937 & 2005 & 1968 & 1951 & 1994 & $n / d$ & 1969 & 1966 & 2001 \\
\hline & $\begin{array}{l}\text { technology } \\
\text { lifecycle }\end{array}$ & Year of 10\% (cumul.MW) & 1880 & 1890 & 1900 & 1922 & 1991 & 1957 & 1956 & 1955 & 2005 & 1976 & 1962 & 1994 & 1945 & 1971 & 1973 & 2001 \\
\hline & $\begin{array}{l}\text { Up-scaling } \\
\text { of unit size }\end{array}$ & Year of $10 \% \mathrm{~K}$ (max. unit capacity) & 1748 & $n / d$ & $n / d$ & $n / d$ & 1999 & 1928 & $n / d$ & $n / d$ & $n / d$ & 1943 & $n / d$ & $n / d$ & $n / d$ & 1958 & 1960 & $n / d$ \\
\hline \multirow{8}{*}{$\begin{array}{l}\text { Ex Ante } \\
\text { END } \\
\text { POINTS }\end{array}$} & $\begin{array}{l}\text { Market } \\
\text { structure }\end{array}$ & Year of peak in number of firms & 1869 & $n / d$ & $n / d$ & $n / d$ & $n / d$ & $n / d$ & 1921 & 1908 & $n / d$ & $\mathrm{n} / \mathrm{d}$ & $n / d$ & $\mathrm{n} / \mathrm{d}$ & $n / d$ & 1973 & $n / d$ & $n / d$ \\
\hline & & $\begin{array}{l}\text { Year of "shakeout" ( } \mathrm{N} \text { falls }-30 \% \\
\text { from the peak) }\end{array}$ & $n / d$ & $n / d$ & $n / d$ & $n / d$ & $n / d$ & $n / d$ & 1924 & 1914 & $n / d$ & $n / d$ & $n / d$ & $n / d$ & $n / d$ & 1979 & $n / d$ & $n / d$ \\
\hline & & $\begin{array}{l}\text { Year of min. market } \\
\text { concentration ratio (CR4) }\end{array}$ & $n / d$ & $n / d$ & $n / d$ & $n / d$ & $n / d$ & $n / d$ & $n / d$ & 1911 & $n / d$ & $n / d$ & $n / d$ & $n / d$ & $n / d$ & $n / d$ & $n / d$ & $n / d$ \\
\hline & $\begin{array}{l}\text { Cost } \\
\text { reduction }\end{array}$ & Year of first $50 \%$ reduction in cost & $\mathrm{n} / \mathrm{a}$ & $n / d$ & 1855 & 1897 & $\mathrm{n} / \mathrm{a}$ & $\mathrm{n} / \mathrm{a}$ & $n / d$ & $\mathrm{n} / \mathrm{a}$ & $\mathrm{n} / \mathrm{a}$ & $\mathrm{n} / \mathrm{a}$ & $n / d$ & $\mathrm{n} / \mathrm{a}$ & $n / d$ & $\mathrm{n} / \mathrm{d}$ & $\mathrm{n} / \mathrm{a}$ & $n / d$ \\
\hline & & Year of max. \% cost reduction & 1727 & $n / d$ & 1855 & 1897 & 2002 & $n / d$ & $n / d$ & 1924 & 2000 & $\mathrm{n} / \mathrm{d}$ & $\mathrm{n} / \mathrm{d}$ & $\mathrm{n} / \mathrm{d}$ & $n / d$ & $n / d$ & $n / d$ & $n / d$ \\
\hline & & $\%$ (max. cost reduction) & $30 \%$ & $n / d$ & $85 \%$ & $63 \%$ & $15 \%$ & $n / d$ & $n / d$ & $25 \%$ & $22 \%$ & $n / d$ & $n / d$ & $n / d$ & $n / d$ & $n / d$ & $n / d$ & $n / d$ \\
\hline & & Description (model, mass prod.) & Newcomen & $n / d$ & $4-4-0$ & $\begin{array}{l}\text { Safety } \\
\text { bike }\end{array}$ & $\begin{array}{l}\text { Danish } \\
\text { model }\end{array}$ & $\begin{array}{l}\text { Conventional } \\
\text { coal PP }\end{array}$ & $n / d$ & $\begin{array}{l}\text { Ford } \\
\text { Model } \\
\text { T }\end{array}$ & mass prod. & $\begin{array}{l}\text { Conventional } \\
\text { gas PP }\end{array}$ & $\mathrm{n} / \mathrm{d}$ & $\mathrm{n} / \mathrm{d}$ & $n / d$ & $n / d$ & PWR & $n / d$ \\
\hline & $\begin{array}{l}\text { User } \\
\text { adoption }\end{array}$ & Year of $2.5 \%$ potential market & 1802 & 1830 & 1846 & 1886 & 1992 & 1917 & 1921 & 1911 & 2005 & 1928 & 1923 & 2000 & $n / d$ & 1959 & 1967 & 1993 \\
\hline \multirow[t]{9}{*}{$\begin{array}{l}\text { Additional } \\
\text { Indicators }\end{array}$} & $\begin{array}{l}\text { Patent } \\
\text { application }\end{array}$ & Year of first peak & $\mathrm{n} / \mathrm{d}$ & $\mathrm{n} / \mathrm{d}$ & $\mathrm{n} / \mathrm{d}$ & $\mathrm{n} / \mathrm{d}$ & 1980 & $n / d$ & $n / d$ & 1897 & $n / d$ & $n / d$ & $n / d$ & $n / d$ & $n / d$ & $n / d$ & $n / d$ & $n / d$ \\
\hline & & $\begin{array}{l}\text { Year of start of } 2 \text { nd wave of } \\
\text { increase }\end{array}$ & $n / d$ & $n / d$ & $n / d$ & $n / d$ & 1996 & $n / d$ & $n / d$ & 1914 & $n / d$ & $n / d$ & $n / d$ & $n / d$ & $n / d$ & $n / d$ & $n / d$ & $n / d$ \\
\hline & $\begin{array}{l}\text { Production } \\
\text { scale up }\end{array}$ & $\begin{array}{l}\text { Year of 10-fold increase in } \\
\text { production }\end{array}$ & $n / a$ & 1820 & $n / a$ & 1862 & $\mathrm{n} / \mathrm{a}$ & $\mathrm{n} / \mathrm{a}$ & $\mathrm{n} / \mathrm{a}$ & $\mathrm{n} / \mathrm{a}$ & $\mathrm{n} / \mathrm{a}$ & $\mathrm{n} / \mathrm{a}$ & $\mathrm{n} / \mathrm{a}$ & $\mathrm{n} / \mathrm{a}$ & $\mathrm{n} / \mathrm{a}$ & no/n.a. & $\mathrm{n} / \mathrm{a}$ & $\mathrm{n} / \mathrm{a}$ \\
\hline & & Year of highest growth & 1720 & 1820 & 1850 & 1862 & 1978 & 1938 & 1901 & 1946 & 1998 & 1945 & 1921 & 1991 & 1956 & 1959 & 1993 & 1980 \\
\hline & & $\%$ & $838 \%$ & $3417 \%$ & $560 \%$ & $7000 \%$ & $450 \%$ & $267 \%$ & $194 \%$ & $328 \%$ & $263 \%$ & $275 \%$ & $132 \%$ & $42 \%$ & $7 \%$ & $863 \%$ & $700 \%$ & $33 \%$ \\
\hline & $\begin{array}{l}\text { Dominant } \\
\text { design }\end{array}$ & Year & 1764 & 1807 & 1829 & 1884 & 1957 & 1920 & 1901 & 1909 & 1946 & 1939 & 1937 & 1985 & 1942 & 1958 & 1970 & 1973 \\
\hline & & Model & Watt engine & $\begin{array}{l}\text { Fulton's } \\
\text { Clermont }\end{array}$ & $\begin{array}{l}\text { Stephenson's } \\
\text { Rocket }\end{array}$ & $\begin{array}{l}\text { Safety } \\
\text { bike }\end{array}$ & $\begin{array}{l}\text { Gedser } \\
\text { wind } \\
\text { turbine }\end{array}$ & $\begin{array}{l}\text { Pulverized } \\
\text { coal system }\end{array}$ & $\begin{array}{l}\text { "diamond } \\
\text { frame" }\end{array}$ & Ford T & $\begin{array}{l}\text { Tucker's } \\
\text { Wheel } \\
\text { motor unit }\end{array}$ & $\begin{array}{l}\text { BBC Velow } \\
\text { plant }\end{array}$ & $\begin{array}{c}\text { Bendix } \\
\text { automatic } \\
\text { wash.mach. }\end{array}$ & $\begin{array}{c}\text { Electronic } \\
\text { ballast }\end{array}$ & $\begin{array}{l}\text { Fluid } \\
\text { Catalytic } \\
\text { cracking }\end{array}$ & $\begin{array}{l}\text { B707/DC- } \\
8\end{array}$ & $\begin{array}{l}\text { LWR } \\
\text { (PWR) }\end{array}$ & $\begin{array}{l}\text { Cooper's } \\
\text { portable } \\
\text { handset }\end{array}$ \\
\hline & $\begin{array}{l}\text { User } \\
\text { adoption }\end{array}$ & Lead user? (Yes/No) & No & No & Yes & No & No & No & No & No & No & No & No & No & No & No & Yes & No \\
\hline & $\begin{array}{l}\text { Up-scaling } \\
\text { of unit size }\end{array}$ & Year of 10\% $\mathrm{K}$ (avg. unit capacity) & 1730 & $1830 \mathrm{~s}$ & 1840 & $n / d$ & 1990 & 1926 & 1941 & 1918 & 1990s (late) & 1906 & 1943 & $n / d$ & 1942 & $<1958$ & 1961 & $n / d$ \\
\hline
\end{tabular}

Notes: $\mathrm{n} / \mathrm{d}=$ no data, $\mathrm{n} / \mathrm{a}=$ not applicable

Sources: see Appendix B 


\section{References}

Abernathy, W.J., Clark, K.B., 1985. Innovation: Mapping the winds of creative destruction. Research Policy 14, 3-22.

Abernathy, W.J, Utterback, J., 1978. Patterns of Industrial Innovation. Technology Review 80, 3-22.

Abernathy, W.J., Clark, K.B., Kantrow, A.M., 1983. Industrial Renaissance: Producing a Competitive Future for America. Basic Books, New York.

Agarwal, R., Bayus, B.L., 2002. The market evolution and sales takeoff of product innovations. Management Science 48(8), 1024-1041.

Anderson, P., Tushman, M., 1990. Technological discontinuities and dominant designs: A cyclical model of technological change. Administrative Science Quarterly 35, 604-634.

Argyres, N., Bigelow, L., Nickerson, J.A., 2011. Dominant design, conpositio desiderata, and the follower's dilemma. Manuscript, Olin Business School, Washington University in St. Louis.

Arrow, K. J., 1962. The Economic Implications of Learning by Doing. Review of Economic Studies 29 (20), 155-173.

Bento, N., 2013. New Evidences in Technology Scaling Dynamics and the Role of the Formative Phase. International Institute for Applied Systems Analysis, IIASA Interim Report 13-004.

Bento, N., Wilson, C., 2014. Formative Phase Lengths for a Sample of Energy Technologies Using a Diverse Set of Indicators. IIASA Interim Report IR-14-009, Laxenbourg.

Bergek, A., Hekkert, M., Jacobsson, S., Markard, J., Sandén, B.A., Truffer, B., 2015. Technological innovation systems in contexts: Conceptualizing contextual structures and interaction dynamics. Environmental Innovation and Societal Transitions 16, 51-64.

Bergek, A., Jacobsson, S., Carisson, B., Lindmark, S., Rickne, A. 2008a. Analyzing the functional dynamics of technological innovation systems: A scheme of analysis. Research Policy 37(3), 407-407.

Bergek, A., Jacobsson, S., Sandén, B.A., 2008b. 'Legitimation'and 'development of positive externalities': two key processes in the formation phase of technological innovation systems. Technology Analysis \& Strategic Management 20(5), 575-592.

Boland, R., Singh, J., Salipanta, P., Aram, J., Fay, S., Kanawattanachai, P. 2001. Knowledge Representations and Knowledge Transfer. Academy of Management Journal 44(2), 393-417. 
Borup, M., Brown, N., Konrad, K., \& Van Lente, H. 2006. The sociology of expectations in science and technology. Technology Analysis \& Strategic Management 18(3-4), 285-298.

Carlsson, B., Stankiewicz, R., 1991. On the nature, function and composition of technological systems. Journal of Evolutionary Economics 1(2), 93-118.

Cowan, R., 1990. Nuclear power reactors: a study in technological lock-in. The Journal of Economic History 50(03), 541-567.

Crafts, N., 2004. Steam as a general purpose technology: A growth accounting perspective. Economic Journal 114(495), 338-351.

Danish Energy Agency 2012. Energy Statistics 2011. HTML-spreadsheet, Available at <http://www.ens.dk/en/info/facts-figures/energy-statistics-indicators-energy-efficiency/annualenergy-statistics> Accessed: 14 August 2012.

de Coninck, H., Benson, S.M., 2014. Carbon Dioxide Capture and Storage: Issues and Prospects. Annual Review of Environment and Resources 39(1): 243-270.

Delina, L.L., Diesendorf, M., 2013. Is wartime mobilisation a suitable policy model for rapid national climate mitigation?. Energy Policy 58(0), 371-380.

Enos, J.L., 1962. Invention and innovation in the petroleum refining industry. In The rate and direction of inventive activity: Economic and social factors (pp. 299-322). NBER.

Fabrizio, K. R., Hawn, O., 2013. Enabling diffusion: How complementary inputs moderate the response to environmental policy. Research Policy 42(5), 1099-1111.

Fouquet, R., 2014. Long run demand for energy services: income and price elasticities over 200 years. Review of Environmental Economics and Policy 8(2) 186-207.

Fouquet, R., 2008. Heat, Power and Light, Revolutions in Energy Services. Edward Elgar, Cheltenham.

Garud R., Karnøe P., 2003. Bricolage versus breakthrough: distributed and embedded agency in technology entrepreneurship. Research policy 32(2), 277-300.

Gipe, P., 1995. Wind energy comes of age. (Vol. 4), John Wiley \& Sons.

Golder, P. N., Tellis, G.J., 1997. Will it ever fly? Modeling the takeoff of really new consumer durables. Marketing Science 16(3), 256-270.

Gort, M., Klepper, S., 1982. Time paths in the diffusion of product innovations. Economic Journal 92, 630-653. 
Gosens, J., Lu, Y., 2013. From lagging to leading? Technological innovation systems in emerging economies and the case of Chinese wind power. Energy Policy 60, 234-250.

Grimes, R.W., W.J., Nuttall, 2010. Generating the Option of a Two-Stage Nuclear Renaissance. Science 329(5993), 799-803.

Grubler, A., 1998. Technology and Global Change. Cambridge University Press.

Grubler, A., Nakicenovic, N.,Victor,D.G., 1999.Dynamics of energy technologies and global change. EnergyPolicy 27(5), 247-280.

Grubler, A., Wilson, C. 2014. Energy Technology Innovation: Learning from Success and Failure. Cambridge University Press, Cambridge UK.

Harborne P., Hendry C., 2009. Pathways to commercial wind power in the US, Europe and Japan: The role of demonstration projects and field trials in the innovation process. Energy Policy 37(9), 3580-3595.

Haszeldine, R.S., 2009. Carbon Capture and Storage: How Green Can Black Be?. Science 325(5948), 16471652.

Haustein, H.D., Neuwirth, E., 1982. Long waves in world industrial production, energy consumption, innovations, inventions, and patents and their identification by spectral analysis. Technological forecasting and social change 22(1), 53-89.

Hendry, C., Harborne, P., Brown, J., 2010. So what do innovating companies really get from publicly funded demonstration projects and trials? Innovation lessons from solar photovoltaics and wind. Energy Policy 38(8), 4507-4519.

Hekkert, M., Suurs, R.A.A., Negro, S., Kuhlmann, S., Smits, R., 2007. Functions of Innovation Systems: A new approach for analysing technological change. Technological Forecasting and Social Change 74 (4), 413-432.

Hekkert, M.P., Negro, S.O., 2009. Functions of innovation systems as a framework to understand sustainable technological change: Empirical evidence for earlier claims. Technological Forecasting and Social Change 76(4), 584-594.

Henderson, R.M., Newell, R.G. (Eds.) 2011. Accelerating Energy Innovation: Insights from Multiple Sectors (Vol. 16529). University of Chicago Press.

IAEA, 2012. Nuclear Power Reactors In The World, 2012 Edition. International Atomic Energy Agency, Reference Data Series No. 2, Vienna. 
IEA, 2006. Light's Labour's Lost: Policies for Energy-efficient Lighting. IEA/OECD, Paris.

Jacobsson, S., 2008. The emergence and growth of a 'biopower' innovation system in Sweden, Energy Policy 36 (4), 1491-508.

Jacobsson, S., Bergek, A., 2012. Innovation system analyses and sustainability transitions: Contributions and suggestions for research. Survey. Environmental Innovation and Societal Transitions (1), 4157.

Jacobsson, S., Bergek, A., 2004. Transforming the energy sector: the evolution of technological systems in renewable energy technology. Industrial and Corporate Change 13, 815-849.

Kanefsky, J.W., Robey, J., 1980. Steam engines in 18th century Britain: a quantitative assessment. TechnolCult 21, 161-186.

Kanefsky, J.W., 1979. The diffusion of power technology in British industry, 1760-1870. (unpub. Ph.D. thesis, Univ.of Exeter, 1979).

Kemp, R., Schot, J., Hoogma, R., 1998. Regime shifts to sustainability through processes of niche formation: the approach of strategic niche management. Technology Analysis \& Strategic Management 10(2), 175-198.

Klepper, S., 1997. Industry Life Cycles. Industrial and Corporate Change 6 (1), 145-181.

Klepper, S., 1996. Entry, exit, growth, and innovation over the product life cycle. American Economic Review 86, 562-583.

Kohli, R., Lehmann, D. R., Pae, J., 1999. Extent and Impact of Incubation Time in New Product Diffusion. Journal of Product Innovation Management 16(2), 134-144.

Markard, J., Hekkert, M., 2013. Technological innovation systems and sectoral change: towards a TIS based transition framework. Paper No. 330 presented at 4th Conference on Sustainability Transitions, June 19-21, 2013, Zurich.

Markard, J., Hekkert, M., Jacobsson, S., 2015. The technological innovation systems framework: Response to six criticisms. Environmental Innovation and Societal Transitions 16, 76-86.

Markard, J., Raven, R., Truffer, B., 2012. Sustainability transitions: An emerging field of research and its prospects. Research Policy 41(6), 955-967.

Markard, J., Truffer, B., 2008. Technological innovation systems and the multi-levelperspective: towards an integrated framework. Research Policy 37, 596-615. 
Maxwell, L., 2009. Who Invented the Electric Washing Machine? An Example of how Patents are Misused by Historians. Available at: <http://www.oldewash.com/articles/Electric_Washer.pdf> (last accessed 28/3/2013)

Meade, N., Islam, T., 2006. Modelling and forecasting the diffusion of innovation-A 25-year review. International Journal of Forecasting 22(3), 519-545.

Mensch, G., 1979. Stalemate in technology: Innovations overcome the depression. Ballinger Pub. Co., Cambridge, MA.

Mitchell, B.R., 1992. International Historical Statistics: Europe 1750-1988. Stockton Press, New York.

Mowery, D.C., Rosenberg, N., 1989. Technology and the Pursuit of Economic Growth. Cambridge University Press.

Murmann, J.P., Frenken K., 2006. Toward a systematic framework for research on dominant designs, technological innovations, and industrial change. Research Policy 35, 925-952.

Nakicenovic, N., 1984. Growth to Limits, Long Waves and the Dynamics of Technology. PhD Dissertation, Vienna University.

National Science Foundation, 2012. Industrial Research and Development Information System: Historical data 1953-2007. Available at: http://www.nsf.gov/statistics/iris/ (accessed 12/12/2012)

Peltoniemi, M., 2011. Reviewing Industry Life-cycle Theory: Avenues for Future Research. International Journal of Management Reviews 13(4), 349-375.

Peres, R., Muller, E., Mahajan, V., 2010. Innovation diffusion and new product growth models: A critical review and research directions. International Journal of Research in Marketing 27(2), 91-106.

Perry, D.B., 1995. Bike Cult: The Ultimate Guide to Human-Powered Vehicles. Four Walls Eight Windows, New York.

Rogers, E.M., 2003. Diffusion of Innovations (5th ed.). Free Press, New York.

Rosenberg, N., Trajtenberg, M., 2004. A general-purpose technology at work: The Corliss steam engine in the late-nineteenth-century United States. The Journal of Economic History 64(01), 61-99.

Rosenberg, N., 1994. Exploring the Black Box: Technology, Economics, and History. Cambridge University Press, Cambridge, UK.

Rosenberg, N., 1982. Inside the black box: Technology and economics. Cambridge University Press. 
Silverberg, G., Verspagen, B., 2003. Breaking the waves: a Poisson regression approach to Schumpeterian clustering of basic innovations. Cambridge Journal of Economics 27(5), 671-693.

Smil, V., 2010. Energy Transitions: History, Requirements, Prospects. Santa Barbara, CA, Praeger.

Stremersch, S., Muller, E., Peres, R., 2010. Does new product growth accelerate across technology generations?. Marketing Letters 21(2), 103-120.

Suurs R.A., Hekkert M.P., Kieboom S., Smits R.E. 2010. Understanding the formative stage of technological innovation system development: The case of natural gas as an automotive fuel. Energy Policy 38(1), 419-431.

Suurs R.A., Hekkert M.P., Smits R.E., 2009. Understanding the build-up of a technological innovation system around hydrogen and fuel cell technologies. International Journal of Hydrogen Energy 34(24), 9639-9654.

Tellis, G., Chandrasekaran, D., 2012. Diffusion and its implications for marketing strategy, in: Shankar V., Carpenter G.S. (Eds.), Handbook of Marketing Strategy. Edward Elgar Publishing, Cheltenham, pp. 376-390.

Tellis, G.J., Stremersch, S., Yin, E., 2003. The international takeoff of new products: The role of economics, culture, and country innovativeness. Marketing Science 22(2), 188-208.

Termuehlen, H., Emsperger, W., 2003. Clean and efficient coal-fired power plants: Development toward advanced technologies. American Society of Mechanical Engineers, New York.

Tran, M., Banister, D., Bishop, J., McCulloch, M., 2012. Realizing the electric-vehicle revolution. Nature Climate Change 2, 328-333.

Tushman, M.L., Anderson, P., 1986. Technological discontinuities and organizational environments. Administrative Science Quarterly 31, pp. 439-465.

U.S. Census Office, 1978. Historical Statistics of the United States, Colonial Times to 1975 - Bicentennial Edition. vol.II, Washington D.C. (and CD-Rom: 1997).

U.S. Department of Transportation (DoT) 1960. Federal Aviation Administration. FAA Statistical Handbook of Aviation, 1960 Edition, Washington, DC.

Utterback, J., Abernathy, W., 1975. A dynamic model of product and process innovation. Omega 3, 639656.

Utterback, J.M., Suarez, F.F., 1993. Innovation, competition, and industry structure. Research Policy, 22, $1-21$. 
Van Duijn, J.J.V., 1983. The long wave in economic life. George Allen \& Unwin Publishers Ltd, London.

Vasseur, V., Kamp, L.M., Negro, S.O., 2013. A comparative analysis of Photovoltaic Technological Innovation Systems including international dimensions: the cases of Japan and The Netherlands. Journal of Cleaner Production 48, 200-210.

Von Hippel, E., 2010. Open user innovation. Handbook of the Economics of Innovation 1, 411-427.

Von Tunzelmann, G.N., 1978. Steam Power and British Industrialisation to 1860. Clarendon Press, Oxford.

Weinert, J.X., 2007. The Rise of Electric Two-Wheelers in China: Factors for their Success and Implications for the Future. Thesis, University of California, Davis.

Weyant, J.P., 2011. Accelerating the development and diffusion of new energy technologies: Beyond the "valley of death". Energy Economics 33(4), 674-682.

Wezel, F., 2002. Different trajectories of industrial evolution: demographical turnover in the European motorcycle industry 1885 - 1993. Working paper, University of Groningen, http://som.eldoc.ub.rug.nl/FILES/reports/themeG/2002/02G37/02g37.pdf (last accessed in August 8, 2011).

Wilson, C., 2012. Up-scaling, formative phases, and learning in the historical diffusion of energy technologies. Energy Policy 50, 81-94.

Wilson, C., Grubler, A., 2011. Lessons from the history of technological change for clean energy scenarios and policies. Natural Resources Forum 35, 165-184.

Wilson, C., Grubler, A., Bauer, N., Krey, V., Riahi K., 2012. Future capacity growth of energy technologies: are scenarios consistent with historical evidence?. Climatic Change 118(2), 381-395.

Winskel M., Radcliffe J., 2014. The Rise of Accelerated Energy Innovation and its Implications for Sustainable Innovation Studies: A UK perspective. Science \& Technology Studies 27(1), 8-33.

Winter, S., 2008. Scaling heuristics shape technology! Should economic theory take notice. Industrial and Corporate Change 17(3), 513-531. 